\title{
Optimizing treatment in undertreated late-stage parkinsonism: a pragmatic randomized trial
}

ALAJ Hommel $^{a}$, MJ Meinders ${ }^{b}$, NJ Weerkamp ${ }^{13}$, C. Richingerg, C. Schmotz ${ }^{g}$, S. Lorenzla, R Dodel $^{\mathrm{h}}$, M Coelho', JJ Ferreiraj, F Tison ${ }^{\mathrm{e}}$, T. Boraud ${ }^{\mathrm{e}}$, WG Meissnere,f ${ }^{\mathrm{f}}$, K Rosqvist', J Timpkai, P Odini, M Wittenbergk ${ }^{k}$, BR Bloem', RT Koopmans ${ }^{d}$, A Schrag ${ }^{c}$ and the CLaSP consortium

${ }^{a}$ Radboud university medical center, Donders Institute for Brain, Cognition and Behaviour, Department of Neurology, Nijmegen, The Netherlands; Groenhuysen Organisation, Roosendaal, the Netherlands.

${ }^{b}$ Radboud university medical center, Radboud Institute for Health Sciences, Scientici Center for Quality of Healthcare, Nijmegen, the Netherlands.

'UCL Queen Square Institute of Neurology, University College London, Royal Free Campus, Rowland Hill street, NW3 2PF, London, UK.

${ }^{a}$ Radboud university medical center, Department of Primary and Community Care, Nijmegen, The Netherlands; Joachim en Anna, Center for Specialized Geriatric Care, Nijmegen, The Netherlands

e Service de Neurologie, CHU de Bordeaux, 33000, Bordeaux, France and Univ. de Bordeaux, Institut des Maladies Neurodégénératives, CNRS, UMR 5293, F-33000 Bordeaux, France.

${ }^{t}$ Dept. Medicine, University of Otago, Christchurch, New Zealand and New Zealand Brain Research Institute, Christchurch, New Zealand

$g$ Interdisziplinäres Zentrum für Palliativmedizin und Klinik für Neurologie Universität München - Klinikum Großhadern, Munich, Germany. Institute of Nursing Science and Practice, Paracelsus Medical University Salzburg, Austria.

${ }^{h}$ Department of Geriatric Medicine, University Hospital Essen, Essen, Germany.

' Division of Neurology, Department of Clinical Sciences, Lund University, Lund, Sweden.

j Instituto de Medicina Molecular Universidad di Lisboa, Lisbon, Portugal.

${ }^{k}$ Coordinating Centre for Clinical Trials (KKS), Philipps-University Marburg, Marburg, Germany.

' Radboud university medical center, Donders Institute for Brain, Cognition and Behavior, Department of Neurology, Nijmegen, The Netherlands.

${ }^{13}$ Department of Neurology, Bronovo Medical Center, The Hague, The Netherlands.

Running title: Optimizing treatment in late-stage parkinsonism

Total number of words: 3.412 words

Corresponding author

Professor Anette Schrag

UCL Queen Square Institute of Neurology

University College London

Royal Free Campus

Rowland Hill street

London NW3 2PF, London, UK

e-mail: a.schrag@ucl.ac.uk 


\section{Abstract [289 words]}

Background Treatment of patients with late-stage parkinsonism is often sub-optimal.

Objective To test the effectiveness of recommendations by a movement disorder specialist with expertise in late-stage parkinsonism. Methods Ninety-one patients with late-stage parkinsonism considered undertreated were included in a pragmatic multi-center randomizedcontrolled trial with six-month follow-up. The intervention group received a letter with treatment recommendations to their primary clinician based on an extensive clinical assessment. Controls received care as usual. The primary outcome was the Unified Parkinson Disease Rating Scale (UPDRS) part-II - Activities of Daily Living. Other outcomes were quality-of-life (PDQ-8), mental health (UPDRS-I), motor function (UPDRS-III), treatment complications (UPDRS-IV), cognition (Mini-mental-state-examination), non-motor symptoms (Non-MotorSymptoms-scale), health status (EQ-5D-5L) and levodopa-equivalent-daily-dose (LEDD). We also assessed adherence to specialist recommendations. In addition to intention-to-treat analyses, a per-protocol analysis was conducted only including those in whom recommendations were at least partially followed. Results Sample size calculation required 288 patients, but only 91 patients could be included. Treating physicians followed recommendations at least partially in 37 (64\%) patients. The intention-to-treat analysis showed no difference in primary outcome (between-group difference $=-1.2, p=0.45$ ), but there was greater improvement for PDQ-8 in the intervention group (between-group difference $=-3.7$, $\mathrm{p}=0.02$ ). The per-protocol analysis confirmed these findings, and also showed less deterioration in UPDRS-part I, greater improvement on UPDRS-total score and greater increase in LEDD in the intervention group. Conclusions There was no improvement on the 
UPDRS-ADL part in this study, which was limited by underrecruitment and limited implementation of recommendations, but there was a positive change in quality of life. These findings suggest that therapeutic gains may be reached even in this vulnerable group of patients with late-stage parkinsonism, but also emphasize the need for better strategies to implement specialist recommendations to further improve outcomes.

Key words: Parkinsonian Disorders, Randomized Controlled Trial, Treatment, Activities of Daily Living, Quality of Life 


\section{Introduction}

Late-stage parkinsonism (LSP) is characterized by a high burden of motor and non-motor symptoms, resulting in dependence in daily functioning, low quality of life and, ultimately, an increased risk of institutionalization and death[1, 2]. Studies suggest that treatment in LSP is often suboptimal[1, 3, 4]. In a Dutch nursing home population, $44 \%$ of patients reported to be "off" most of the day[4] and received a seemingly too low dose of dopaminergic treatment. Also, patients in this study perceived their professional caregivers as having insufficient knowledge of Parkinson's disease (PD)[3].

Although treatment in LSP is more complex than in earlier disease stages[1], movement disorders experts are potentially well equipped to address this complexity as they frequently treat patients with PD. However, LSP-patients may be underrepresented in their patient population, as LSP-patients are frequently unable to travel for appointments with a neurologist, or for hospital-based assessments of their condition. A model of care with a movement disorder expert's advice supporting the treatment decisions of the patient's primary physician in LSP, has not been tested for feasibility or effectiveness in LSP.

The primary aim of this European pragmatic study was to evaluate the effect of recommendations made by movement disorder experts in a population of undertreated LSPpatients on clinically relevant outcomes measures, such as activities of daily living, motor symptoms, non-motor symptoms and quality of life.

\section{Methods}

Study design 
This study is part of the Care of Late-Stage Parkinsonism-study (CLaSP-study)[5]. To assess the effect of the intervention, we designed a multi-center pragmatic parallel randomized controlled trial that allowed us to observe the effectiveness embedded within existing clinical care routines in four European countries (UK, France, Sweden and the Netherlands). Centres in two other countries, who participated in the CLaSP-study, did not participate in this trial due to organizational and regulatory issues. To establish an estimation of impact, the study had a pragmatic design and was executed in routine clinical practice[6]. The study recruitment was set up to be as inclusive as possible. Allocation to the intervention versus control group followed a 3:1 ratio to ensure that as many patients as possible could potentially benefit from the intervention. The study consisted of a baseline measurement following inclusion of the patient in the study, and a follow-up measurement after six months.

\section{Study sample}

Patients recruitment took place from January 2015 until December 2017. Last follow-up measurement was June 2018. Undertreated LSP-patients formed the target population. As these patients normally do not access expert research centres, recruitment was set-up to include care-pathways outside of routine recruitment pathways like expert clinics. Care settings included in the recruitment were nursing homes (France, Sweden, the Netherlands), general practices (UK), non-research centre hospitals (Sweden, the Netherlands), patient-advocate organizations (UK) and PD patient registries (Sweden). Patients with a disease duration of 7 years or longer were invited for participation if they either had disease stage Hoehn and Yahr stage $\geq 4$ or a Schwab and England-score $\leq 50 \%$. This allowed for inclusion of patients with 
disability not only due to motor but also non-motor problems, such as dementia, neuropsychiatric symptoms and autonomic dysfunction [7]. Undertreatment was defined by the presence of any insufficiently treated symptoms or problems (for full set of possible symptoms and problems see table 1). PD and atypical parkinsonian disorders were diagnosed using established clinical criteria[8-10]. Patients with atypical parkinsonism were purposely not excluded as their care needs are likely comparable to those of patients with late-stage PD[1113]. Exclusion criteria were: 1. a diagnosis of normal pressure hydrocephalus or drug-induced parkinsonism (except if parkinsonism persisted after discontinuation of the causative drug for at least 6 months), 2. dementia prior to or at time of parkinsonism diagnosis; 3 . having seen a movement disorder specialist recently ( $\leq 4$ months); and 4 . the patient was unable to comply with changes to treatments (for example unable to attend physiotherapy in their region).

\section{Intervention}

Our intervention consisted of a letter with specific recommendations to optimize treatment and care, formulated by a movement disorder expert, based on a comprehensive clinical assessment by the researchers, as part of the CLaSP protocol [5]. The researchers assessed the symptoms and discussed these with the movement disorder expert, who drafted the letter. Each study centre assigned one expert to write this letter. To align the recommendations between the centres, the experts used an extensive, predesigned study guideline. During a face-to-face meeting, the group of movement disorder experts in the study developed this consensus-based recommendation guideline based on combined treatment recommendations of multiple European and International guidelines[14-19]. (see supplemental file). The 
guideline covered four distinct domains: 1. dopaminergic treatment, 2. non-dopaminergic treatment, 3. mental health medications, and 4. allied health care, social services and nursing care.

For each patient, the letter with recommendations was sent to the physician who was identified by the patient as being the physician responsible for the parkinsonism treatment, i.e., the primary physician. The movement disorder expert drafted the letter after the CLaSP baseline assessment, considering current and previous disease factors, review of medications and current medical and social care arrangements. The movement disorder expert sent the letter to the primary physician with the invitation to contact the expert if the recommendations were unclear or additional advice was needed. The decision to implement the recommendations remained with the patient's primary physician. Patients in the control group received care as usual during the follow-up period, but had the possibility to receive a letter with recommendations from the expert after the follow-up assessment, i.e. outside the current study window. For ethical reasons, if the assessments revealed issues requiring urgent treatment, these were communicated to the primary physicians in both treatment and control group.

\section{Outcomes}

The primary outcome was the Unified Parkinson's Disease Rating Scale - part II: activities of daily living (UPDRS-II)[20] at 6 months, and secondary outcomes were quality of life (Parkinson Disease Quality of Life Questionnaire 8-items version; PDQ-8), mental health (UPDRS-I), motor function (UPDRS-III), complications of therapy (UPDRS-IV), total UPDRS 
score (UPDRS-total), cognition (Mini-mental state examination; MMSE), non-motor symptoms (Non-Motor Symptoms scale; NMSs) and health status (EQ-5D-5L). We also assessed the levodopa equivalent daily dose (LEDD)[21-26]. We chose activities of daily living as the primary outcome, because it contributes to the disease burden of patient and caregiver, and to adverse outcomes like nursing home placement[27-29]. Outcomes were assessed twice: at baseline and at the primary end-point after six months. Assessors visited the patients mostly at home, but if possible, patients came to the study centre. Process information was collected to assess implementation of the treatment recommendations and barriers to implementation. During the follow-up meeting the assessor discussed the treatment recommendations with the patient and scored recommendations as completely followed, partially followed, not followed, or unknown. The assessor contacted the primary physician for an interview to find out if recommendations were followed, and to assess barriers for implementations. For the latter, we used a structured questionnaire based on the Cabana model[30-32], which identifies barriers in knowledge, attitude or behavior for guideline adherence among neurologist and GP[31, 32]. Barriers listed in the original questionnaire that were not applicable to our intervention were removed, leaving a comprehensive list of eleven items (see table 4).

Randomization and concealment of allocation

Permuted block randomization was used, stratified by country, presence of dementia and residency (nursing home or similar/ home). Randomization was performed centrally at the Coordinating Centre for Clinical Trials (Marburg, Germany). Assessors and patients were not blinded. 


\section{Statistical analysis}

A power calculation was performed to estimate the target sample size, based on the primary outcome: UPDRS - part II: activities of daily living.[33] An independent sample $t$-test was used and the assumptions were a difference in change of 4.8 points between both treatment groups, a standard deviation of 10 points for difference in change and non-participating and dropout rates of $20 \%$ each. 288 patients had to be included to achieve a power of $80 \%$ with a twosided significance level of $5 \%$. The current study was terminated at the end of the funding period, prior to reaching the target sample size.

Missing data were substituted with an imputation strategy, preferably according to the user guidelines of each measurement instrument. As such, we used the validated protocol for handling missing data of the UPDRS[34], by which imputations were allowed if the number of missing items did not exceed 1 for the UPDRS-I, 1 for the UPDRS-II and 7 for the UPDRS-III. No imputation was allowed for UPDRS-IV. Imputation for NMS items is possible if less than 15 items were missing. The case-specific mean of completed items was used for imputation of missing UPDRS and NMS items. No valid imputation strategies exist for the other questionnaires and analyses were performed on the available data.

For the intention-to-treat analysis, we performed multivariate linear regression analyses with the outcome measures at follow-up as dependent variables and the group (intervention or care as usual) and baseline score of the outcome measure as the independent variables, correcting for relevant covariates (i.e., presence of dementia, presence of informal caregiver, residency, age, gender and disease duration). We present the covariate-adjusted mean difference 
between treatment groups and the $95 \%$ confidence intervals. We also performed an exploratory per protocol analysis, only including in the intervention group those patients in whom the recommendations were completely or partially followed; all others were included in the control group. Descriptives are presented with mean and standard deviation for normallydistributed variables and with median and interquartile range for non-normally distributed variables. Critical $p$-value for statistical significance was set at 0.05 . All analyses were performed using Statistical Package of Social Sciences, version 22.

Standards protocol approvals, regulations, and patient consent

This study was in compliance with the Helsinki Declaration (World Medical Association Declaration of Helsinki 1997). Detailed oral and written information was given to the patients and their informant to ensure that the patients fully understood the potential risks and benefits of the study. Written consent was given by patients or, if patients lacked capacity, by a legal guardian, in accordance with local ethical and legal regulations. The study protocol was approved by the local ethics committees of all participating study sites (London: Camden and Islington NRES Committee 14/LO/0612, Lisbon: Centro Hospitalar Lisboa Norte, DIRCLN19SET2014-275, Lund: EPN Regionala etikprovningsnamnden (EPN Regional Ethics Name) JPND NC 559-002, Bordeaux: CPP Sud-Ouest et Outre-Mer III 2014/85, , Marburg: EthikKommission bei der Landesarztekammer Hessen (Ethics Commission at the State Medical Association Hesse, MC 309/2014). Nijmegen: Radboud universitair medisch centrum, Concernstaf Kwaliteit en Veiligheid, Commissie Mensgebonden Onderzoek Regio ArnhemNijmegen (Radboud university medical center,Group staff Quality and Safety Human Research 
Committee, Arnhem-Nijmegen region, DJ/CMO300). Inclusion was possible if patients gave their written informed consent. The protocol was registered at ClinicalTrials.gov as NCT02333175 on 07/01/2015.

\section{Data availability}

Anonymized data can be shared with qualified investigators on request.

\section{Results}

Out of the 477 patients in the overall CLaSP study in the participating centres with ethical approval, 167 had not received care by a movement disorder specialist within the last four months. Out of these 91 could be included, of whom 70 were randomized to the intervention group and 21 to the control group. Reasons for non-inclusion, including four who declined participation, are listed in figure 1. Patients in the intervention group did not differ in baseline characteristics from controls except for the presence of an informal caregiver that was more present in the intervention group in the per protocol group allocation (table 2). Overall, 58 (83\%) patients in the intervention group and $18(86 \%)$ patients in the control group completed the trial (figure 1).

In the intention-to-treat analysis, there was no difference in change in the UPDRS ADL scores, i.e. the primary outcome measure, between the intervention and control group at six months (between-group difference $=-1.2,95 \% \mathrm{Cl}=-4.2$ to $1.8, \mathrm{p}=0.45$ ). The group difference in UPDRS motor and total score showed a trend towards improvement (between-group 
difference $=-5.1,95 \% \mathrm{Cl}=-10.7$ to $0.6, \mathrm{p}=0.08$ ). Quality of life had improved at six months for patients in the intervention group, but had worsened in controls (PDQ-8, between-group difference $=-3.7,95 \% \mathrm{Cl}=-6.7$ to $-0.9, \mathrm{p}=0.01$; figure $2 \mathrm{a}$ and supplementary material). All other secondary outcomes showed no group differences.

The per-protocol analysis (figure $2 \mathrm{~b}$ and supplementary material) confirmed these findings, showing no between-group difference in the UPDRS ADL score, but again a difference in PDQ8 in favour of the intervention group (between-group difference $=-2.7,95 \% \mathrm{Cl}=-5.1$ to -0.3 , $\mathrm{p}=0.03$ ). The difference in UPDRS total score as well as part I scores also reached significance (UPDRS total: between-group difference $=-7.4,95 \% \mathrm{Cl}=-14.6$ to $-0.2, \mathrm{p}=0.04$; UPDRS part I: between-group difference $=-1.1,95 \% \mathrm{Cl}=-2.2$ to $-0.4, \mathrm{p}=0.04)$, with a trend for part III scores (between-group difference $=-4.2,95 \% \mathrm{Cl}=-9.2$ to $0.8, \mathrm{p}=0.10$ ). Finally, patients in the intervention group had a larger increase in LEDD (between-group difference $=165 \mathrm{mg}$, $95 \% \mathrm{Cl}=51$ to $279, \mathrm{p}=0.01)$. A sensitivity analysis with presence of a caregiver as a covariate in the per-protocol analysis gave similar results (data not shown). Different definitions of the per protocol groups did not change the main results (supplementary materials).

\section{Process Analysis of implementation}

The primary physicians receiving the letter with recommendations followed these recommendations completely in only 16 (28\%) patients and partially in 21 (36\%). Recommendations were not followed in $18(31 \%)$ and remained unclear in $3(5 \%)$ patients. The extent to which recommendations were followed, differed per type of recommendation and ranged from $15 \%$ for referral to physiotherapist (complete or partially followed: $5 / 33$ ) to $50 \%$ 
for recommendations about dopaminergic treatment (complete or partially followed: 20/40). In total, 36 recipients of the letter with recommendations were contacted to assess barriers for implementing recommendations. As the main reason for not following the recommendations, the physicians reported to have experienced an inability to reconcile patient's preferences with the recommendation $(10 / 36=28 \%)$, lack of time $(8 / 36=22 \%)$ and lack of outcome expectancy $(7 / 36=19 \%)$ (table 3$).$ In addition to the items from the Cabana model, the open question retrieved eight additional barriers, reported in total 12 times (33\%; see table 4 , item 14). The most frequent additional barrier to not following recommendation was a change in physician $(5 / 36=15 \%)$

\section{Discussion}

Despite not reaching the required sample size, this pragmatic trial is the largest study to date in the underserved and poorly studied population of LSP. A letter to the primary physician with recommendations to optimize treatment by a specialist, based on standardised assessments by a trained assessor, did not improve the primary outcome measure of UPDRS ADL score compared to care as usual, but there was a significant improvement in quality of life scores in both the intention-to-treat and per-protocol-analysis, with an effect size exceeding the minimally important benefit [35]. In addition, there was a trend towards better outcome on the UPDRS part III as well as UPDRS total scores in the intention-to-treat population, and a significant improvement on the UPDRS total and part I scores in the per-protocol analysis, together with a greater increase in LEDD, suggesting that adjustment of dopaminergic medication partially mediated the observed effects. This notion is also in line with earlier work showing dopaminergic undertreatment in LSP patients[3, 4], and also with other studies showing that levodopa improved motor and non-motor features in LSP patients[36-38]. The significant difference between intervention and control group in the PDQ-8 suggests that the 
intervention had a positive impact on the patients' overall quality of life that was not captured by the UPDRS-ADL part. Several other studies on complex multidisciplinary interventions in PD failed to show an impact on ADL-measures, indicating that these outcomes may not be sensitive enough to capture relevant change in these situations[39-42]. A quality of life measure may be a more appropriate tool, particularly in the advanced, complex stage of PD, where treatment is increasingly aiming to optimize quality of life instead of pursuing improvement of objective functioning. Social elements of the disease, like feeling embarrassed by symptoms or having trouble in personal relations, are represented in our quality of life measurement but not in the other outcome measures, which could explain the lack of finding on other outcome measures in the intention-to-treat analysis. Furthermore, patient-reported outcome measures, such as quality of life measures, are increasingly used as primary outcome measures in large trials $[43,44]$. Finding a change on a patient-reported measure, like quality of life measures, but not on clinician-completed outcome measures has been reported by other trials $[45,46]$, indicating that patients may report improvements that are not appreciated in assessment by others, including using standardised assessment tools .

It is also noteworthy that our process evaluation revealed that whilst physicians followed recommendations to at least some degree in most patients $(64 \%$ either completely or partially), many other recommendations were not followed and several barriers to implementing the recommendations were identified. These findings indicate suboptimal implementation of the advice of movement disorder experts communicated in a letter, as typically done in standard outpatient settings, and that other medical consultation models may be more appropriate for this population. This is in line with previous studies, with more elaborate interventions, that reported low adherence in interventions aiming at improving quality of disease management in elderly populations [47-51]. Perhaps the most important result of this trial is that we identified several barriers for the implementation of the advice. The most common reasons were difficulty in reconciling the advice with the patient's preference, a lack of time, a lack of outcome expectancy and change in primary physicians. 
This may in part be related to the constraints of the trial, with standardised recommendations, assessments rather than ongoing care, and assessment of complex patients with a trained study assessor rather than the movement disorder specialist who made the recommendations following discussion. It has previously been shown that understanding the medicine-taking behavior of patients should be the first step in optimizing therapy, which requires knowledge and consideration of a patient's personal beliefs about their medicines[52]. However, it may also suggest that recommendations by the specialist require greater interaction with the primary care physician to adjust to the circumstances of their care, availability and access to treatments such occupational therapy, a PD specialist nurse, and wishes of patients with LSP, or that the healthcare system is ill-equipped to implement the intervention. Further work is needed to explore this and future research should take note of these barriers in developing more elaborate interventions which are better suited to the local health care system.

The pragmatic design of this trial had limitations which may have affected our findings. Primarily due to lack of ethics approval in two participating countries and many patients already receiving specialist care, we did not reach the targeted study sample size. We extended the study recruitment window and developed several new strategies to boost recruitment, but this population remains difficult to include in clinical trials. As a consequence, we cannot draw any firm conclusions on the impact of our intervention on thethe primary outcome measure. In addition, we conducted the study in several countries across Europe with different health care provisions and these difference could have concealed a greater effect. Furthermore, we included patients with all types of parkinsonism, not all of whom would respond to antiparkinsonian medication changes. However, only three individuals who completed the trial did not have a diagnosis of PD and the main results were comparable when we only analysed typical patients. The movement disorder specialist had limited contact with participants, as assessments were done by trained staff, recommendations were standardised, availability and ease of access, and the beliefs on their treatment were not assessed behaviour. As discuss above, these are is likely to have 
affected to the implementation of the recommendations [52]. In addition, movement disorder experts had limited contact with most of participants' healthcare providers, and greater interaction may have improved adherence to the recommendations. Nevertheless, our methodology mirrored typical daily practice in current healthcare systems, where infrequent specialist appointments with recommendation letters for other involved healthcare providers, are typical forms of intervention, and continuity of care by a specialist, good interaction with primary physicians, and sufficient time in primary care are often not available. Our results suggest that in order to achieve the best results with significant improvement of outcomes for activities of daily living and quality of life, specialist recommendations need to be accompanied by strategies to increase implementation. Close interaction with primary physicians, sufficient time for discussion with patients and their carers on preferences, wishes and beliefs and the benefits of the recommended treatments, and long term follow-up with continuity of care may be helpful to achieve this. LSP poses particular challenges to provision and participation in care, including cognitive deficits, low mood, apathy or fatigue which can limit participation in some non-pharmacological interventions [53], and there are limitations in ability to attend appointments and high caregiver burden [12, 54, 55]. Novel approaches to providing specialist input for this population, including community-based support, palliative care models with neurological input, online support and other modalities may be required to maximise the benefit from specialist recommendations to improve quality of life and disability [56].

In summary, whilst there was no improvement of ADL on the UPDRS-ADL part in this study, which was limited by underrecruitment and limited implementation of recommendations, we found that specialist recommendations communicated by letter had a positive impact on quality of life in patients with LSP. Our results also demonstrate the limitations in implementation of treatment recommendations communicated by letter to the primary treating physicians in this complex and vulnerable patient group.

\section{Acknowledgement}


We would like to thank patients and their families participating in the study and all staff members in the recruiting centres who participated in the CLaSP consortium. Special thanks to the following members of the consortium: Brice Laurens, Umberto Spampinato, Alexandra Foubert-Samier, Sylvain Vergnet, Jeanette Härnberg and Inga-Lill Svensson. We would further like to thank the European Commission for funding this study (Joint Programme Neurodegenerative Disease Research "European research projects for the evaluation of health care policies, strategies and interventions for Neurodegenerative Diseases"; through national funding bodies in all six countries: Economic and Social Research Council ES/L009250/1; BMBF, Marburg, Germany 01ED1403A, Munich, Germany 01ED1403B, Bordeaux, France: ANR-13-JPHC-0001-07, Lisbon, Portugal: HC/0002/2012, Lund, Sweden: HC-559-002, Nijmegen, Holland, 733051003. We would like to thank the following organisations for cofunding: Groenhuysen organisation, Stichting Beroepsopleiding Huisartsen, National Institute for Health Research UCL/UCLH Biomedical Research Centre.

We would like to thank our funding sources: the European Commission AS was supported by the National Institute for Health Research UCL/UCLH Biomedical Research Centre. DH was supported by Groenhuysen Organisation and Stichting Beroepsopleiding Huisartsen. SL has received honoraria for lectures from $U C B, A b b V i e$. We received no industry-sponsored funds.

\section{Conflict of interest}

The authors have no conflicts of interest to report related to the present study.

\section{Supplementary material}

Full description of the intention-to-treat and per protocol analysis are available in the supplementary material, including the estimated group differences adjusted for baseline 
measurements and covariates: age, gender, disease duration, residence in nursing home and presence of dementia. The consensus-based study guideline of recommendations and the frequencies of recommendations are included in the supplementary materials. A sensitivity analysis of the per-protocol group allocation on the outcome measures is shown in the supplementary materials. 


\section{Reference List}

[1] Coelho M, Ferreira JJ (2012) Late-stage Parkinson disease. Nat Rev Neurol 8, 435-442.

[2] Weerkamp NJ, Tissingh G, Poels PJ, Zuidema SU, Munneke M, Koopmans RT, Bloem BR (2014) Parkinson disease in long term care facilities: a review of the literature. J Am Med Dir Assoc 15, 90-94.

[3] van Rumund A, Weerkamp N, Tissingh G, Zuidema SU, Koopmans RT, Munneke M, Poels PJ, Bloem BR (2014) Perspectives on Parkinson disease care in Dutch nursing homes. J Am Med Dir Assoc 15, 732-737.

[4] Weerkamp NJ, Zuidema SU, Tissingh G, Poels PJ, Munneke M, Koopmans RT, Bloem BR (2012) Motor profile and drug treatment of nursing home residents with Parkinson's disease. J Am Geriatr Soc 60, 2277-2282.

[5] Balzer-Geldsetzer M, Ferreira J, Odin P, Bloem BR, Meissner WG, Lorenzl S, Wittenberg M, Dodel R, Schrag A (2018) Study protocol: Care of Late-Stage Parkinsonism (CLaSP): a longitudinal cohort study. BMC Neurol 18, 185.

[6] Zwarenstein M, Treweek S, Gagnier JJ, Altman DG, Tunis S, Haynes B, Oxman AD, Moher D (2008) Improving the reporting of pragmatic trials: an extension of the CONSORT statement. Bmj 337, a2390.

[7] Schwab RS EAJ, editors (1969) Projection technique for evaluating surgery in Parkinson's disease, E \& S Livingstone, Edinburgh:.

[8] Hughes AJ, Daniel SE, Kilford L, Lees AJ (1992) Accuracy of clinical diagnosis of idiopathic Parkinson's disease: a clinico-pathological study of 100 cases. J Neurol Neurosurg Psychiatry 55, 181-184.

[9] Gilman S, Wenning GK, Low PA, Brooks DJ, Mathias CJ, Trojanowski JQ, Wood NW, Colosimo C, Durr A, Fowler CJ, Kaufmann H, Klockgether T, Lees A, Poewe W, Quinn N, Revesz T, Robertson D, Sandroni P, Seppi K, Vidailhet M (2008) Second consensus statement on the diagnosis of multiple system atrophy. Neurology 71, 670-676.

[10] Hoglinger GU, Respondek G, Stamelou M, Kurz C, Josephs KA, Lang AE, Mollenhauer B, Muller U, Nilsson C, Whitwell JL, Arzberger T, Englund E, Gelpi E, Giese A, Irwin DJ, Meissner WG, Pantelyat A, Rajput A, van Swieten JC, Troakes C, Antonini A, Bhatia KP, Bordelon Y, Compta Y, Corvol JC, Colosimo C, Dickson DW, Dodel R, Ferguson L, Grossman M, Kassubek J, Krismer F, Levin J, Lorenzl S, Morris HR, Nestor P, Oertel WH, Poewe W, Rabinovici G, Rowe JB, Schellenberg GD, Seppi K, van Eimeren T, Wenning GK, Boxer AL, Golbe LI, Litvan I (2017) Clinical diagnosis of progressive supranuclear palsy: The movement disorder society criteria. Mov Disord 32, 853-864.

[11] Bouca-Machado R, Titova N, Chaudhuri KR, Bloem BR, Ferreira JJ (2017) Palliative Care for Patients and Families With Parkinson's Disease. Int Rev Neurobiol 132, 475-509.

[12] Schmotz C, Richinger C, Lorenzl S (2017) High Burden and Depression Among Late-Stage Idiopathic Parkinson Disease and Progressive Supranuclear Palsy Caregivers. J Geriatr Psychiatry Neurol 30, 267-272.

[13] Wiblin L, Lee M, Burn D (2017) Palliative care and its emerging role in Multiple System Atrophy and Progressive Supranuclear Palsy. Parkinsonism Relat Disord 34, 7-14.

[14] Bloem BR VLT, Keus SHJ, De Beer H, Poot E, Buskens E, Aarden W, Munneke M, namens de Centrale Werk groep Multidisciplinaire richtlijn Parkinson 2006-2010. (2010)

Multidisciplinaire richtlijn Ziekte van Parkinson, Van Zuiden Communications, Alphen aan den Rijn

[15] Ferreira JJ, Katzenschlager R, Bloem BR, Bonuccelli U, Burn D, Deuschl G, Dietrichs E, Fabbrini G, Friedman A, Kanovsky P, Kostic V, Nieuwboer A, Odin P, Poewe W, Rascol O, Sampaio C, Schupbach M, Tolosa E, Trenkwalder C, Schapira A, Berardelli A, Oertel WH (2013) Summary 
of the recommendations of the EFNS/MDS-ES review on therapeutic management of Parkinson's disease. Eur J Neurol 20, 5-15.

[16] Horstink M, Tolosa E, Bonuccelli U, Deuschl G, Friedman A, Kanovsky P, Larsen JP, Lees A, Oertel W, Poewe W, Rascol O, Sampaio C, European Federation of Neurological S, Movement Disorder Society-European S (2006) Review of the therapeutic management of Parkinson's disease. Report of a joint task force of the European Federation of Neurological Societies (EFNS) and the Movement Disorder Society-European Section (MDS-ES). Part II: late (complicated) Parkinson's disease. Eur J Neurol 13, 1186-1202.

[17] Kalf JG dSB, Bonnier M, Hofman M,, Kanters J KJ, Miltenburg M, Bloem BR, Munneke M. (2008) Logopedie bij de ziekte van Parkinson, een richtlijn van de Nederlandse Vereniging voor Logopedie en Foniatrie, Nederlandse Vereniging voor Logopedie en Foniatrie/Uitgeverij Lemma, Woerden/Den Haag.

[18] Lennaerts H, Groot M, Rood B, Gilissen K, Tulp H, van Wensen E, Munneke M, van Laar T, Bloem BR (2017) A Guideline for Parkinson's Disease Nurse Specialists, with Recommendations for Clinical Practice. J Parkinsons Dis 7, 749-754.

[19] Domingos J, Keus SHJ, Dean J, de Vries NM, Ferreira JJ, Bloem BR (2018) The European Physiotherapy Guideline for Parkinson's Disease: Implications for Neurologists. J Parkinsons Dis 8, 499-502.

[20] Martinez-Martin P, Fontan C, Frades Payo B, Petidier R (2000) Parkinson's disease: quantification of disability based on the Unified Parkinson's Disease Rating Scale. Neurologia 15, 382-387.

[21] Brooks R (1996) EuroQol: the current state of play. Health Policy 37, 53-72.

[22] Chaudhuri KR, Martinez-Martin P, Brown RG, Sethi K, Stocchi F, Odin P, Ondo W, Abe K, Macphee G, Macmahon D, Barone P, Rabey M, Forbes A, Breen K, Tluk S, Naidu Y, Olanow W, Williams AJ, Thomas S, Rye D, Tsuboi Y, Hand A, Schapira AH (2007) The metric properties of a novel non-motor symptoms scale for Parkinson's disease: Results from an international pilot study. Mov Disord 22, 1901-1911.

[23] Folstein MF, Folstein SE, McHugh PR (1975) "Mini-mental state". A practical method for grading the cognitive state of patients for the clinician. J Psychiatr Res 12, 189-198.

[24] Peto V, Jenkinson C, Fitzpatrick R (1998) PDQ-39: a review of the development, validation and application of a Parkinson's disease quality of life questionnaire and its associated measures. J Neurol 245 Suppl 1, S10-14.

[25] Yesavage JA, Brink TL, Rose TL, Lum O, Huang V, Adey M, Leirer VO (1982) Development and validation of a geriatric depression screening scale: a preliminary report. J Psychiatr Res 17, 37-49.

[26] Tomlinson CL, Stowe R, Patel S, Rick C, Gray R, Clarke CE (2010) Systematic review of levodopa dose equivalency reporting in Parkinson's disease. Mov Disord 25, 2649-2653.

[27] Barone P, Antonini A, Colosimo C, Marconi R, Morgante L, Avarello TP, Bottacchi E, Cannas A, Ceravolo G, Ceravolo R, Cicarelli G, Gaglio RM, Giglia RM, lemolo F, Manfredi M, Meco G, Nicoletti A, Pederzoli M, Petrone A, Pisani A, Pontieri FE, Quatrale R, Ramat S, Scala R, Volpe G, Zappulla S, Bentivoglio AR, Stocchi F, Trianni G, Dotto PD (2009) The PRIAMO study: A multicenter assessment of nonmotor symptoms and their impact on quality of life in Parkinson's disease. Mov Disord 24, 1641-1649.

[28] Goetz CG, Stebbins GT (1993) Risk factors for nursing home placement in advanced Parkinson's disease. Neurology 43, 2227-2229.

[29] Aarsland D, Larsen JP, Karlsen K, Lim NG, Tandberg E (1999) Mental symptoms in Parkinson's disease are important contributors to caregiver distress. Int J Geriatr Psychiatry 14, 866-874.

[30] Cabana MD, Rand CS, Powe NR, Wu AW, Wilson MH, Abboud PA, Rubin HR (1999) Why don't physicians follow clinical practice guidelines? A framework for improvement. Jama 282, 1458-1465.

[31] AU K (2005) in Fachbereic Erziehungswissenschaften und Psychologie. Freie Universität Berlin, Berlin. 
[32] Larisch A, Oertel WH, Eggert K (2009) Attitudes and barriers to clinical practice guidelines in general and to the guideline on Parkinson's disease. A National Survey of German neurologists in private practice. J Neurol 256, 1681-1688.

[33] Makoutonina M, lansek R, Simpson P (2010) Optimizing care of residents with Parkinsonism in supervised facilities. Parkinsonism Relat Disord 16, 351-355.

[34] Goetz CG, Luo S, Wang L, Tilley BC, LaPelle NR, Stebbins GT (2015) Handling missing values in the MDS-UPDRS. Mov Disord 30, 1632-1638.

[35] Peto V, Jenkinson C, Fitzpatrick R (2001) Determining minimally important differences for the PDQ-39 Parkinson's disease questionnaire. Age Ageing 30, 299-302.

[36] Fabbri M, Coelho M, Abreu D, Guedes LC, Rosa MM, Costa N, Antonini A, Ferreira JJ (2016) Do patients with late-stage Parkinson's disease still respond to levodopa? Parkinsonism Relat Disord 26, 10-16.

[37] Fabbri M, Guimaraes I, Cardoso R, Coelho M, Guedes LC, Rosa MM, Godinho C, Abreu D, Goncalves N, Antonini A, Ferreira JJ (2017) Speech and Voice Response to a Levodopa Challenge in Late-Stage Parkinson's Disease. Front Neurol 8, 432.

[38] Rosqvist K, Horne M, Hagell P, Iwarsson S, Nilsson MH, Odin P (2018) Levodopa Effect and Motor Function in Late Stage Parkinson's Disease. J Parkinsons Dis 8, 59-70.

[39] Clarke CE, Patel S, Ives N, Rick CE, Woolley R, Wheatley K, Walker MF, Zhu S, Kandiyali R, Yao G, Sackley CM (2016) Clinical effectiveness and cost-effectiveness of physiotherapy and occupational therapy versus no therapy in mild to moderate Parkinson's disease: a large pragmatic randomised controlled trial (PD REHAB). Health Technol Assess 20, 1-96.

[40] Ashburn A, Fazakarley L, Ballinger C, Pickering R, McLellan LD, Fitton C (2007) A randomised controlled trial of a home based exercise programme to reduce the risk of falling among people with Parkinson's disease. J Neurol Neurosurg Psychiatry 78, 678-684.

[41] Canning CG, Sherrington C, Lord SR, Close JC, Heritier S, Heller GZ, Howard K, Allen NE, Latt MD, Murray SM, O'Rourke SD, Paul SS, Song J, Fung VS (2015) Exercise for falls prevention in Parkinson disease: a randomized controlled trial. Neurology 84, 304-312.

[42] Eggers C, Dano R, Schill J, Fink GR, Hellmich M, Timmermann L (2018) Patient-centered integrated healthcare improves quality of life in Parkinson's disease patients: a randomized controlled trial. J Neurol 265, 764-773.

[43] Gray R, Ives N, Rick C, Patel S, Gray A, Jenkinson C, McIntosh E, Wheatley K, Williams A, Clarke CE (2014) Long-term effectiveness of dopamine agonists and monoamine oxidase $B$ inhibitors compared with levodopa as initial treatment for Parkinson's disease (PD MED): a large, open-label, pragmatic randomised trial. Lancet 384, 1196-1205.

[44] Williams A, Gill S, Varma T, Jenkinson C, Quinn N, Mitchell R, Scott R, Ives N, Rick C, Daniels J, Patel S, Wheatley K (2010) Deep brain stimulation plus best medical therapy versus best medical therapy alone for advanced Parkinson's disease (PD SURG trial): a randomised, openlabel trial. Lancet Neurol 9, 581-591.

[45] Chagas MH, Zuardi AW, Tumas V, Pena-Pereira MA, Sobreira ET, Bergamaschi MM, dos Santos AC, Teixeira AL, Hallak JE, Crippa JA (2014) Effects of cannabidiol in the treatment of patients with Parkinson's disease: an exploratory double-blind trial. J Psychopharmacol 28, 1088-1098.

[46] Li F, Harmer P, Liu Y, Eckstrom E, Fitzgerald K, Stock R, Chou LS (2014) A randomized controlled trial of patient-reported outcomes with tai chi exercise in Parkinson's disease. Mov Disord 29, 539-545.

[47] Voigt-Radloff S, Graff M, Leonhart R, Hull M, Rikkert MO, Vernooij-Dassen M (2011) Why did an effective Dutch complex psycho-social intervention for people with dementia not work in the German healthcare context? Lessons learnt from a process evaluation alongside a multicentre RCT. BMJ Open 1, e000094.

[48] van Knippenberg RJM, de Vugt ME, Smeets CMJ, Myin-Germeys I, Verhey FRJ, Ponds RW (2018) Dealing with daily challenges in dementia (deal-id study): process evaluation of the 
experience sampling method intervention 'Partner in Sight' for spousal caregivers of people with dementia. Aging Ment Health 22, 1199-1206.

[49] Appelhof B, Bakker C, van Duinen-van den IJCL, Zwijsen SA, Smalbrugge M, Verhey FRJ, de Vugt ME, Zuidema SU, Koopmans R (2018) Process Evaluation of an Intervention for the Management of Neuropsychiatric Symptoms in Young-Onset Dementia. J Am Med Dir Assoc 19, 663-671.

[50] Leontjevas R, Gerritsen DL, Koopmans RT, Smalbrugge M, Vernooij-Dassen MJ (2012) Process evaluation to explore internal and external validity of the "Act in Case of Depression" care program in nursing homes. J Am Med Dir Assoc 13, 488.e481-488.

[51] N. Linnan AS (2002) Process Evaluation for Public Health Interventions and Research: An Overview, Jossey Bass, San Francisco, CA.

[52] Grosset KA, Reid JL, Grosset DG (2005) Medicine-taking behavior: implications of suboptimal compliance in Parkinson's disease. Mov Disord 20, 1397-1404.

[53] Ferrazzoli D, Ortelli P, Maestri R, Bera R, Gargantini R, Palamara G, Zarucchi M, Giladi N, Frazzitta G (2017) Focused and Sustained Attention Is Modified by a Goal-Based Rehabilitation in Parkinsonian Patients. Front Behav Neurosci 11, 56.

[54] Coelho M, Marti MJ, Tolosa E, Ferreira JJ, Valldeoriola F, Rosa M, Sampaio C (2010) Latestage Parkinson's disease: the Barcelona and Lisbon cohort. J Neurol 257, 1524-1532.

[55] Weerkamp NJ, Tissingh G, Poels PJ, Zuidema SU, Munneke M, Koopmans RT, Bloem BR (2013) Nonmotor symptoms in nursing home residents with Parkinson's disease: prevalence and effect on quality of life. J Am Geriatr Soc 61, 1714-1721.

[56] Bloem BR, Dorsey ER, Okun MS (2020) The Coronavirus Disease 2019 Crisis as Catalyst for Telemedicine for Chronic Neurological Disorders. JAMA Neurol. 
Total number of figures and tables: 7

Table 1. Definition of undertreated LSP patients

More than 1 of the following:

- Troublesome motor parkinsonism (including nocturnal motor problems).

- Levodopa-induced motor complications, including Off-time $>50 \%$ of waking day, moderately disabling dyskinesias or off-time dystonia.

- PD dementia (defined according to MDS Task Force definition (Dubois et al. 2007), and not treated with cholinesterase inhibitors.

- Depression not receiving adequate treatment.

- Clinically relevant neuropsychiatric symptoms, among which psychotic symptoms, agitation/ aggression; anxiety and irritability/ liability.

- Clinically relevant symptomatic orthostatic hypotension, pain, constipation, urinary symptoms, insomnia or daytime sleepiness.

- Regular falling

- Treatment with medications that are associated with exacerbation of PD-related problems: (a) typical antipsychotics other than quetiapine or clozapine, anticholinergics, benzodiazepines, pills with protein rich meal, antihypertensives in symptomatic hypotensive patients, valproate, calcium antagonists, other medications with side effect exacerbating PD motor or non-motor symptoms

- Increased risk of contractures and skin ulceration

- Inadequate management of dysphagia with risk of choking, of dysarthria or of hypersalivation

- Living in an inadequate home environment. 


\section{Figure 1. Flow Diagram of recruitment of cohort and trial population}

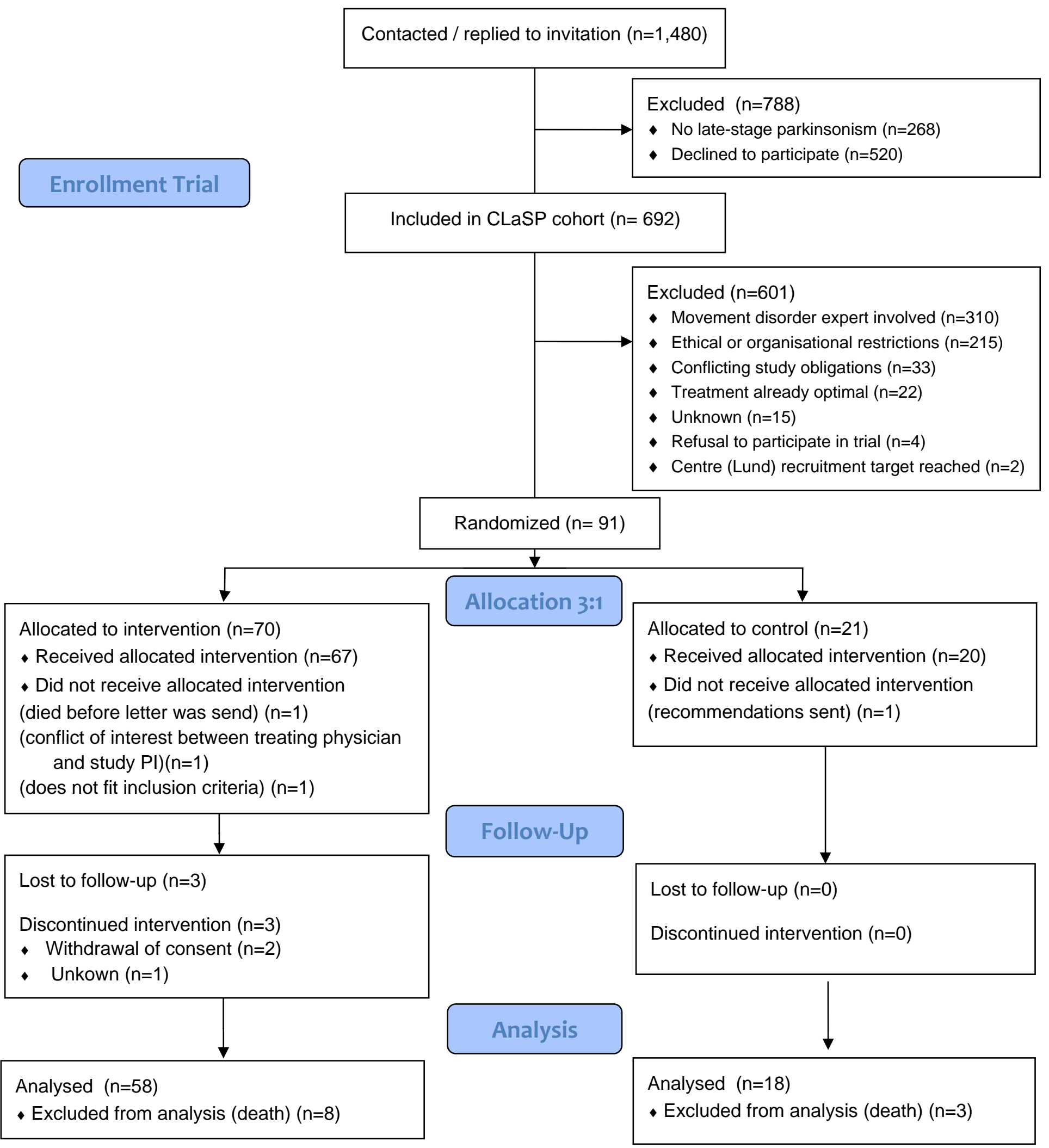


Table 2. Univariate comparative analysis of baseline characteristics

\begin{tabular}{|c|c|c|c|c|c|c|}
\hline & \multicolumn{3}{|c|}{ Intention-to-treat analysis } & \multicolumn{3}{|c|}{ Per-protocol analysis } \\
\hline & Intervention & Control & $\mathrm{P}$ & Intervention & Control & $\mathrm{P}$ \\
\hline Age, years, median (IQR) & $80(74-85)$ & $84(76-88)$ & 0.15 & $78(74-84)$ & $83(74-88)$ & 0.11 \\
\hline Age of onset, years, mean (SD) & $65.0(10.3)$ & $63.4(13.1)$ & 0.55 & $64.6(9.8)$ & $64.5(13.2)$ & 0.98 \\
\hline $\begin{array}{l}\text { Disease duration, years, median } \\
\text { (IQR) }\end{array}$ & $14(10-18)$ & $16(12-23)$ & 0.13 & $14(9-17)$ & $15(11-20)$ & 0.44 \\
\hline Women, n (\%) & $36(51)$ & $6(29)$ & 0.07 & $17(46)$ & $16(44)$ & 0.90 \\
\hline Dementia, n (\%) & $31(44)$ & $9(43)$ & 0.91 & $16(50)$ & $12(33)$ & 0.38 \\
\hline Informal care giver present, n (\%) & $46(66)$ & $11(52)$ & 0.27 & $32(86)$ & $24(67)$ & 0.04 \\
\hline $\begin{array}{l}\text { Living in nursing home, } \mathrm{n}(\%) \\
\text { Diagnosis, } \mathrm{n}(\%)\end{array}$ & $42(60)$ & $12(57)$ & 0.82 & $18(49)$ & $23(64)$ & 0.19 \\
\hline Parkinson's disease & 67 & 20 & 0.93 & 35 & 35 & 7 \\
\hline $\begin{array}{l}\text { Atypical parkinsonism } \\
\text { Site, } \mathrm{n}(\%)\end{array}$ & 3 & 1 & & 2 & 1 & \\
\hline London & $7(10)$ & $1(5)$ & & $2(5)$ & $2(6)$ & 0.97 \\
\hline Bordeaux & $4(6)$ & $2(10)$ & & $2(5)$ & $3(8)$ & \\
\hline Lund & $42(60)$ & $13(62)$ & & $24(65)$ & $23(64)$ & \\
\hline Nijmegen & $17(24)$ & $5(24)$ & & $9(25)$ & $8(22)$ & \\
\hline Hoehn and Yahr stage, n (\%) & & & & & & \\
\hline Stage 3 & $4(6)$ & 0 & 0.52 & $2(5)$ & 0 & 0.20 \\
\hline Stage 4 & $39(56)$ & $13(62)$ & & $21(57)$ & $26(72)$ & \\
\hline Stage 5 & $27(39)$ & $8(38)$ & & $14(38)$ & $10(28)$ & \\
\hline
\end{tabular}


Figure 2A. Intention-to-treat analysis CLaSP-trial
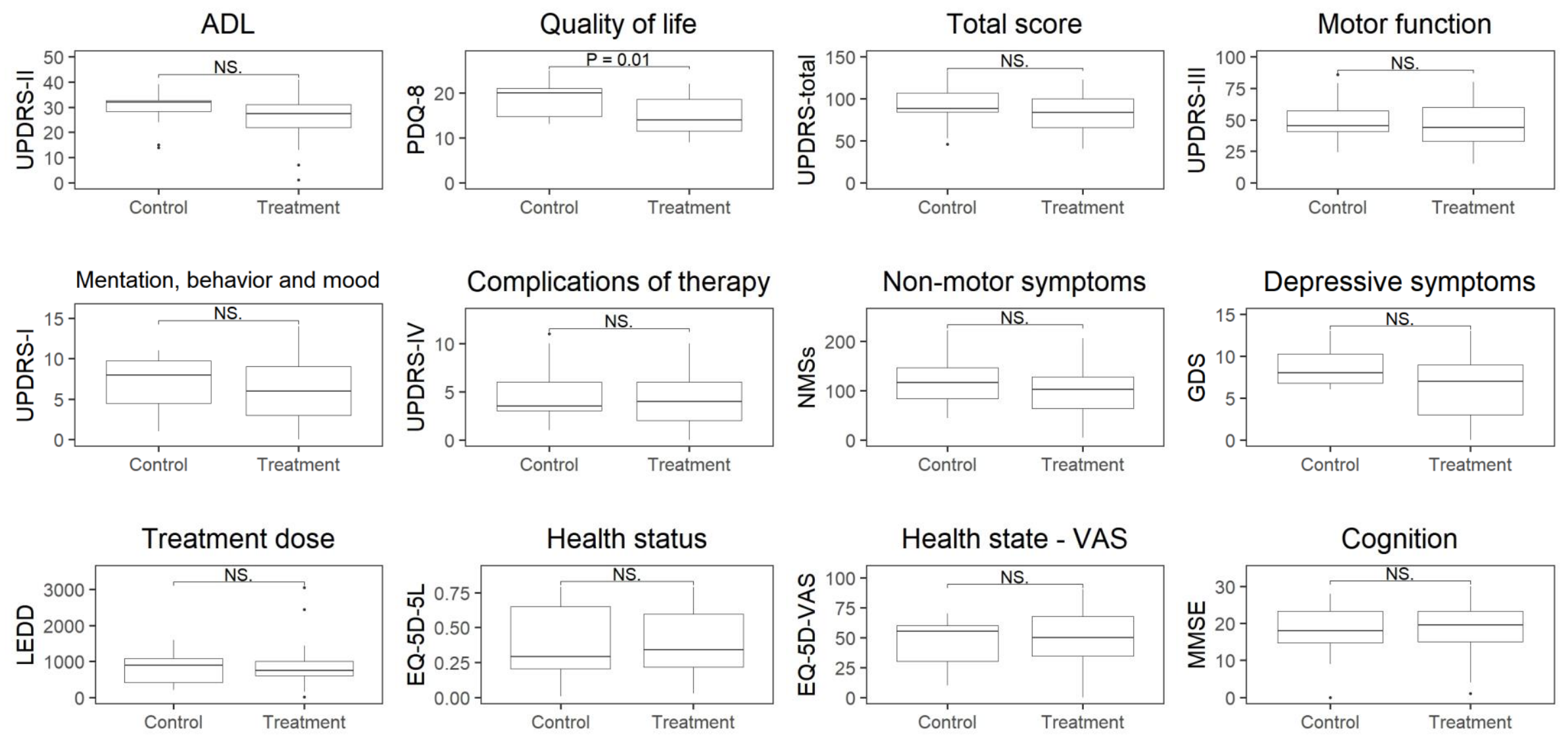

Shown are boxplots of primary and secondary outcome measures at follow-up. Abbreviations: Unified Parkinson Disease Rating scale (UPDRS), Mini-mental state examination (MMSE), non-motor symptoms scale (NMSs), Geriatric Depression Scale - 15 items (GDS), Parkinson Disease Questionnaire (PDQ), EuroQol-5 dimensions (EQ-5D-5L), Visual Analogue Scale (VAS), Levodopa Equivalent Daily Dosis (LEDD), non-significant (NS.)

Figure 2B. Per-protocol analysis CLaSP-trial 
ADL

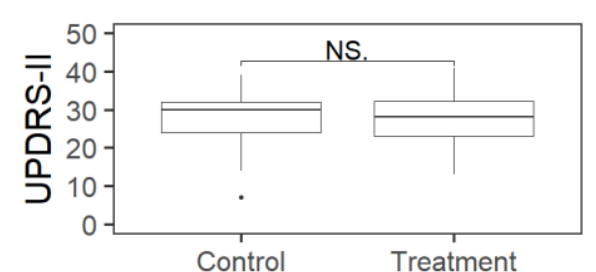

Mentation, behavior and mood

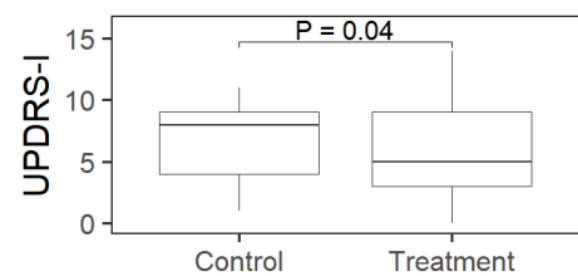

Treatment dose

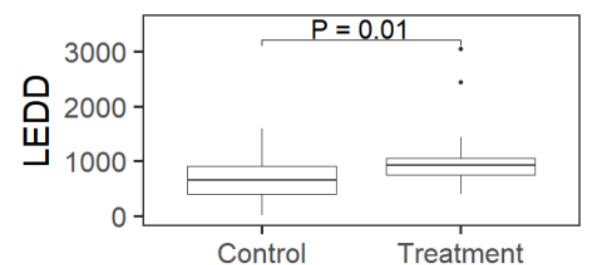

Quality of life

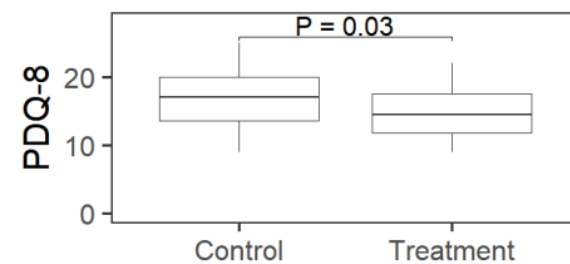

Complications of therapy

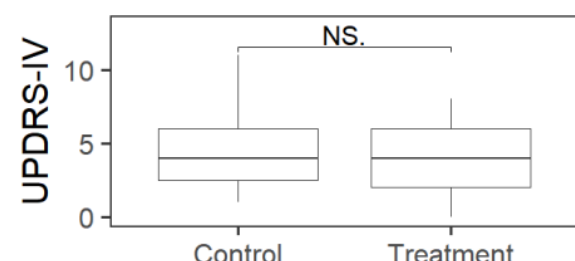

Health status

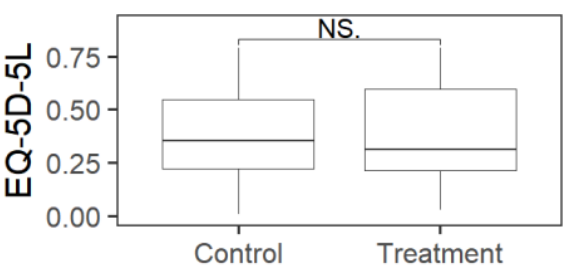

Total score

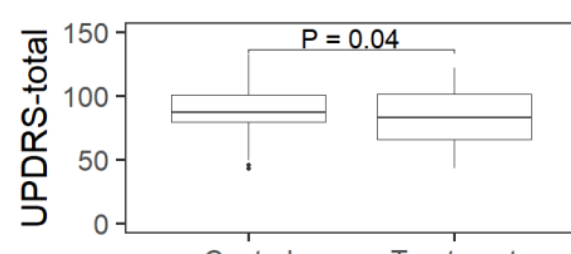

Control Treatment

Non-motor symptoms
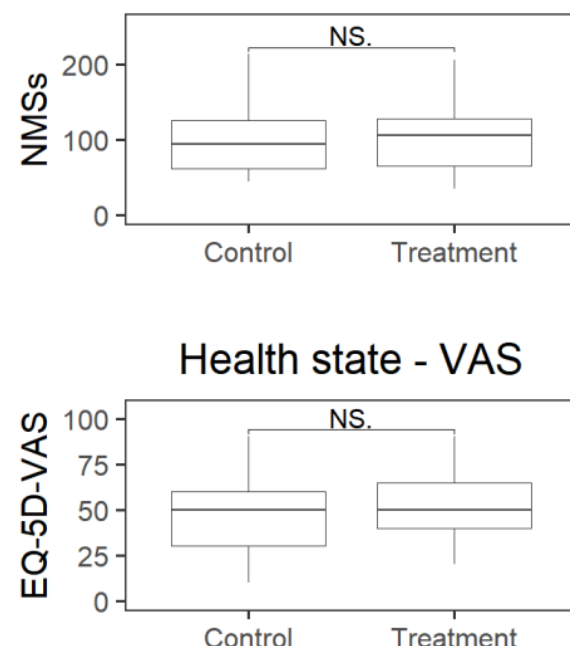

Motor function

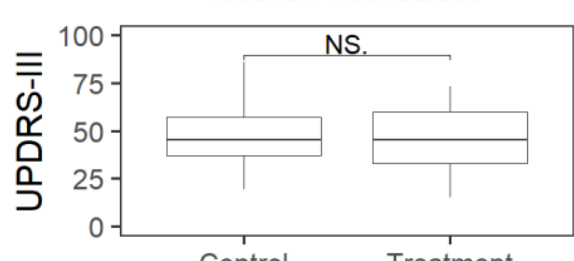

Control Treatment

Depressive symptoms
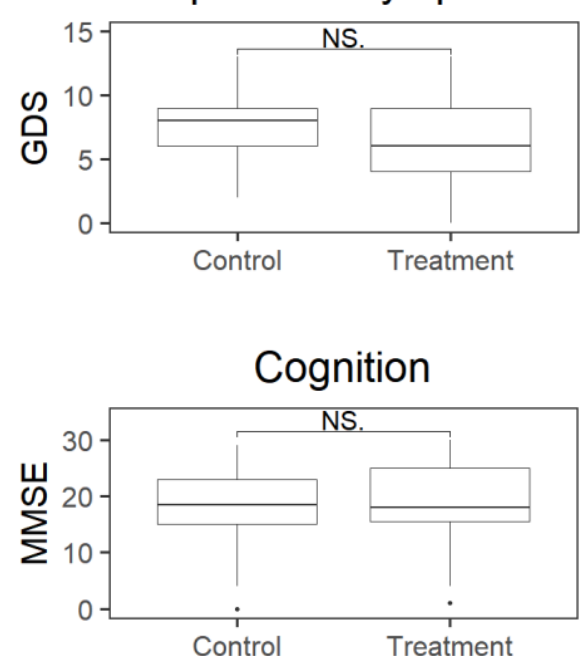

Shown are boxplots of primary and secondary outcome measures at follow-up. Abbreviations: Unified Parkinson Disease Rating scale (UPDRS), Mini-mental state examination (MMSE), non-motor symptoms scale (NMSs), Geriatric Depression Scale - 15 items (GDS), Parkinson Disease Questionnaire (PDQ), EuroQol-5 dimensions (EQ-5D-5L), Visual Analogue Scale (VAS), Levodopa Equivalent Daily Dosis (LEDD), non-significant (NS.) 
Table 3. Performance of recommendation letter as implementation strategy

\begin{tabular}{|c|c|c|c|c|c|}
\hline \multirow[t]{2}{*}{ Type of recommendation } & \multirow{2}{*}{$\begin{array}{l}\text { Number of participants } \\
\text { receiving recommendation }\end{array}$} & \multicolumn{4}{|c|}{ Recommendation followed } \\
\hline & & $Y_{e s}^{a}$ & Partially & No & Unkown \\
\hline Overall & 58 & $16(28 \%)$ & $21(36 \%)$ & $18(31 \%)$ & $3(5 \%)$ \\
\hline \multicolumn{6}{|l|}{ Per domain } \\
\hline Dopaminergic treatment & 40 & $14(35 \%)$ & $6(15 \%)$ & $7(18 \%)$ & $13(33 \%)$ \\
\hline $\begin{array}{l}\text { Non-dopaminergic } \\
\text { treatment }\end{array}$ & 32 & $8(25 \%)$ & $3(9 \%)$ & $8(25 \%)$ & $13(41 \%)$ \\
\hline Mental health treatment & 43 & $13(30 \%)$ & $2(5 \%)$ & $12(28 \%)$ & $16(37 \%)$ \\
\hline \multicolumn{6}{|l|}{$\begin{array}{l}\text { Referral to allied health } \\
\text { care }\end{array}$} \\
\hline Physiotherapy & 33 & $4(12 \%)$ & $1(3 \%)$ & $14(42 \%)$ & $14(42 \%)$ \\
\hline $\begin{array}{l}\text { Speech and language } \\
\text { therapy }\end{array}$ & 10 & $4(40 \%)$ & 0 & $4(40 \%)$ & $2(20 \%)$ \\
\hline Occupational therapy & 9 & $2(22 \%)$ & 0 & $4(40 \%)$ & $3(33 \%)$ \\
\hline Parkinson nurse & 2 & 0 & 0 & $1(50 \%)$ & $1(50 \%)$ \\
\hline Psychosocial support & 5 & 0 & 0 & $2(40 \%)$ & $3(60 \%)$ \\
\hline $\begin{array}{l}\text { Referral to other } \\
\text { specialties }\end{array}$ & 11 & $1(9 \%)$ & $1(9 \%)$ & $1(9 \%)$ & $8(73 \%)$ \\
\hline
\end{tabular}

alf multiple recommendations were given the participants was scored as 'Yes' in 'Overall' if one of the recommendations was followed completely. 
Table 4. Barriers of implementations of recommendations as reported by letter recipients

\begin{tabular}{l|c} 
Number of letter recipients consulted & 36 \\
\hline & \\
\hline Inability to reconcile patient preference with management advice & $10(28 \%)$ \\
\hline Lack of time & $8(22 \%)$ \\
\hline Lack of outcome expectancy & $7(19 \%)$ \\
\hline Lack of agreement with the management advice & $4(11 \%)$ \\
\hline User unfriendly letter & $3(9 \%)$ \\
\hline Presence of contradictory management advice & $2(6 \%)$ \\
\hline Lack of self-efficacy & $2(6 \%)$ \\
\hline Inertia in changing previous practice routine & $1(3 \%)$ \\
\hline Lack of knowledge on the content of the management advice & $1(3 \%)$ \\
\hline Lack of actuality of management advice & $1(3 \%)$ \\
\hline Lack of confidence in movement disorder specialist & 0 \\
\hline Lack of (financial) reimbursement & 0 \\
\hline Perceived increase in malpractice liability & 0 \\
\hline Other: & \\
- Recommendations were deemed inappropriate for this age and comorbidity & $5(14 \%)$ \\
- Lack of knowledge and experience in nursing staff who are needed for & $1(3 \%)$ \\
implementation & $1(3 \%)$ \\
- Indication not severe enough to warrant intervention & $1(3 \%)$ \\
- misunderstood intend of letter; thought it was only informative & $1(3 \%)$ \\
- Treating physician had no trusting relation with patient & $1(3 \%)$ \\
- Change in physician during treatment period & $1(3 \%)$ \\
- Recommendations send to a physician who is not the primary treating physician & $1(3 \%)$ \\
- Recommendation described were "too idealized"
\end{tabular}

Proportions of the barriers per recipients are shown following a structured interview using the Cabana model and one open-ended question allowing other barriers to be mentioned. Multiple barriers could be report per recipient. 
Supplementary material. Appendix A. Intention-to-treat analysis CLaSP-trial

\begin{tabular}{|c|c|c|c|c|c|c|}
\hline & \multicolumn{2}{|c|}{ Baseline } & \multicolumn{2}{|c|}{ Follow-up } & \multicolumn{2}{|c|}{$\begin{array}{c}\text { Difference between groups at } \\
\text { follow-up }\end{array}$} \\
\hline & $\mathbf{N}$ & Median (IQR) & $\mathbf{N}$ & Median (IQR) & Mean $(95 \% \mathrm{Cl})$ & p-value \\
\hline \multicolumn{7}{|c|}{ Primary outcome measure } \\
\hline \multicolumn{7}{|c|}{ Unified Parkinson Disease Rating Scale - Part II } \\
\hline Intervention & 68 & $26(22-31)$ & 56 & $28(22-31)$ & $-1.2(-4.2$ to 1.8$)$ & 0.45 \\
\hline Care as usual & 21 & $29(26-33)$ & 18 & $32(28-33)$ & ref. & \\
\hline \multicolumn{7}{|c|}{ Secondary outcome measures } \\
\hline \multicolumn{7}{|c|}{ Unified Parkinson Disease Rating Scale - Part I } \\
\hline Intervention & 69 & $6(4-8)$ & 56 & $6(3-9)$ & $-0.9(-2.1$ to 0.4$)$ & 0.17 \\
\hline Care as usual & 21 & $5(3-8)$ & 18 & $8(4-10)$ & ref. & \\
\hline \multicolumn{7}{|c|}{ Unified Parkinson Disease Rating Scale - Part III } \\
\hline Intervention & 67 & $45(33-56)$ & 56 & $44(32-60)$ & $-5.1(-10.7$ to 0.6$)$ & 0.08 \\
\hline Care as usual & 21 & $47(40-53)$ & 18 & $45(40-60)$ & ref. & \\
\hline \multicolumn{7}{|c|}{ Unified Parkinson Disease Rating Scale - Part IV } \\
\hline Intervention & 69 & $4(2-6)$ & 56 & $4(2-6)$ & $-0.1(-1.4$ to 1.3$)$ & 0.93 \\
\hline Care as usual & 21 & $5(3-8)$ & 18 & $4(3-6)$ & ref. & \\
\hline \multicolumn{7}{|c|}{ Unified Parkinson Disease Rating Scale - Total } \\
\hline Intervention & 69 & $79(66-96)$ & 56 & $82(65-100)$ & $-7.8(-16.4$ to 0.8$)$ & 0.07 \\
\hline Care as usual & 21 & $88(70-98)$ & 18 & $89(83-111)$ & ref. & \\
\hline \multicolumn{7}{|c|}{ Geriatric Depression Scale - 15 items } \\
\hline Intervention & 47 & $7(3-10)$ & 43 & $7(3-9)$ & $+0.9(-1.2$ to 3.0$)$ & 0.39 \\
\hline Care as usual & 14 & $7(5-10)$ & 12 & $8(6-11)$ & ref. & \\
\hline \multicolumn{7}{|c|}{ Non Motor Symptom scale } \\
\hline Intervention & 67 & $102(62-130)$ & 55 & $106(77-143)$ & $+0.1(-21.0$ to 21.2$)$ & 0.99 \\
\hline Care as usual & 19 & $116(82-147)$ & 18 & $119(99-145)$ & ref. & \\
\hline \multicolumn{7}{|c|}{ Mini-Mental State Examination (increase equals better score) } \\
\hline Intervention & 67 & $21(15-25)$ & 52 & $20(15-24)$ & $+0.7(-1.4$ to 2.8$)$ & 0.51 \\
\hline Care as usual & 19 & $20(13-26)$ & 16 & $18(14-24)$ & ref. & \\
\hline \multicolumn{7}{|c|}{ Parkinson Disease Questionnaire - 8 items } \\
\hline Intervention & 36 & $16(12-19)$ & 32 & $14(11-19)$ & $-3.8(-6.7$ to -0.9$)$ & 0.01 \\
\hline Care as usual & 12 & $14(12-18)$ & 8 & $20(14-23)$ & ref. & \\
\hline \multicolumn{7}{|c|}{$E Q-5 D-5 L$ - index score (increase equals better score) } \\
\hline Intervention & 54 & $0.2(0.1-0.6)$ & 45 & $0.3(0.0-0.5)$ & $+0.1(-0.1$ to 0.3$)$ & 0.29 \\
\hline Care as usual & 18 & $0.3(0.2-0.6)$ & 14 & $0.1(-0.1-0.4)$ & ref. & \\
\hline \multicolumn{7}{|c|}{ EQ-5D-5L VAS score (increase equals better score) } \\
\hline Intervention & 54 & $50(39-60)$ & 43 & $50(34-70)$ & $+4.8(-9.4$ to 19.0$)$ & 0.50 \\
\hline Care as usual & 16 & $50(25-58)$ & 12 & $55(30-60)$ & ref. & \\
\hline \multicolumn{7}{|c|}{ Levodopa equivalent daily doses } \\
\hline Intervention & 62 & $700(525-866)$ & 56 & 755 (606-999) & $+108(-26$ to 242$)$ & 0.11 \\
\hline Care as usual & 21 & $798(525-1129)$ & 18 & $887(400-1171)$ & ref. & \\
\hline
\end{tabular}

Group differences were estimated using linear regression models adjusting for baseline measurements and covariates: age, gender, disease duration, residence in nursing home and presence of dementia. For all score increase equals worse score, except if otherwise stated. Abbreviations: Interquartile range (IQR), Standard deviation (SD), $95 \%$ Confidence Interval (95\% CI) 
Appendix B. Per protocol analysis CLaSP-trial

\begin{tabular}{|c|c|c|c|c|c|c|}
\hline & \multicolumn{2}{|c|}{ Baseline } & \multicolumn{2}{|c|}{ Follow-up } & \multicolumn{2}{|c|}{$\begin{array}{c}\text { Difference between groups at } \\
\text { follow-up }\end{array}$} \\
\hline & $\mathbf{N}$ & Median (IQR) & $\mathbf{N}$ & Median (IQR) & Mean $(95 \% \mathrm{Cl})$ & p-value \\
\hline \multicolumn{7}{|c|}{ Primary outcome measure } \\
\hline \multicolumn{7}{|c|}{ Unified Parkinson Disease Rating Scale - Part II } \\
\hline Intervention & 37 & $28(22-32)$ & 36 & $28(23-33)$ & $-1.1(-3.6$ to 1.3$)$ & 0.37 \\
\hline Care as usual & 36 & $26(22-31)$ & 36 & $30(24-32)$ & ref. & \\
\hline \multicolumn{7}{|c|}{ Secondary outcome measures } \\
\hline \multicolumn{7}{|c|}{ Unified Parkinson Disease Rating Scale - Part I } \\
\hline Intervention & 37 & $5(4-8)$ & 37 & $5(3-9)$ & $-1.1(-2.2$ to -0.4$)$ & 0.04 \\
\hline Care as usual & 36 & $5(3-7)$ & 35 & $8(4-9)$ & ref. & \\
\hline \multicolumn{7}{|c|}{ Unified Parkinson Disease Rating Scale - Part III } \\
\hline Intervention & 37 & $43(33-54)$ & 37 & $45(32-60)$ & $-4.2(-9.2$ to 0.8$)$ & 0.10 \\
\hline Care as usual & 35 & $42(31-51)$ & 35 & $45(37-57)$ & ref. & \\
\hline \multicolumn{7}{|c|}{ Unified Parkinson Disease Rating Scale - Part IV } \\
\hline Intervention & 37 & $4(2-7)$ & 37 & $4(2-6)$ & $-0.6(-1.7$ to 0.6$)$ & 0.32 \\
\hline Care as usual & 36 & $5(2-7)$ & 35 & $4(2-6)$ & ref. & \\
\hline \multicolumn{7}{|c|}{ Unified Parkinson Disease Rating Scale - Total } \\
\hline Intervention & 37 & $82(66-102)$ & 37 & $79(66-96)$ & $-7.4(-14.6$ to -0.2$)$ & 0.04 \\
\hline Care as usual & 36 & $78(65-96)$ & 36 & $87(72-101)$ & ref. & \\
\hline \multicolumn{7}{|c|}{ Geriatric Depression Scale - 15 items } \\
\hline Intervention & 24 & $7(2-8)$ & 29 & $6(4-9)$ & $-0.3(-2.0$ to 1.5$)$ & 0.75 \\
\hline Care as usual & 29 & $7(5-11)$ & 25 & $8(6-10)$ & ref. & \\
\hline \multicolumn{7}{|c|}{ Non Motor Symptom scale } \\
\hline Intervention & 36 & $106(62-132)$ & 37 & $106(82-145)$ & $+0(-17.9$ to 17.9$)$ & 1.00 \\
\hline Care as usual & 35 & $94(61-128)$ & 34 & $114(89-145)$ & ref. & \\
\hline \multicolumn{7}{|c|}{ Mini-Mental State Examination (increase equals better score) } \\
\hline Intervention & 36 & $21(16-26)$ & 35 & $18(15-26)$ & $+0.7(-1.2$ to 2.5$)$ & 0.48 \\
\hline Care as usual & 35 & $21(16-25)$ & 32 & $19(15-23)$ & ref. & \\
\hline \multicolumn{7}{|c|}{ Parkinson Disease Questionnaire - 8 items } \\
\hline Intervention & 19 & $15(12-19)$ & 20 & $15(11-19)$ & $-2.7(-5.1$ to -0.3$)$ & 0.03 \\
\hline Care as usual & 24 & $15(12-18)$ & 19 & $17(13-20)$ & ref. & \\
\hline \multicolumn{7}{|c|}{$E Q-5 D-5 L$ - index score (increase equals better score) } \\
\hline Intervention & 30 & $0.3(0.1-0.6)$ & 30 & $0.3(0.1-0.6)$ & $+0.1(-0.1$ to 0.3$)$ & 0.25 \\
\hline Care as usual & 31 & $0.3(0.2-0.6)$ & 28 & $0.2(-0.1-0.4)$ & ref. & \\
\hline \multicolumn{7}{|c|}{ EQ-5D-5L VAS score (increase equals better score) } \\
\hline Intervention & 30 & $50(40-61)$ & 29 & $50(38-68)$ & $+5.9(-6.2$ to 18.0$)$ & 0.33 \\
\hline Care as usual & 30 & $50(30-53)$ & 25 & $50(28-65)$ & ref. & \\
\hline \multicolumn{7}{|c|}{ Levodopa equivalent daily doses } \\
\hline Intervention & 37 & $798(600-947)$ & 37 & $929(750-1060)$ & +165 (51 to 279$)$ & 0.01 \\
\hline Care as usual & 36 & $653(490-888)$ & 36 & $658(400-934)$ & ref. & \\
\hline
\end{tabular}

Group differences were estimated using linear regression models adjusting for baseline measurements and covariates: age, gender, disease duration, residence in nursing home and presence of dementia. For all score increase equals worse score, except if otherwise stated. Abbreviations: Interquartile range (IQR), Standard deviation (SD), $95 \%$ Confidence Interval (95\% CI) 
Appendix C. Consensus based study treatment guideline.

\begin{tabular}{|c|c|c|c|}
\hline Problem & Advice directed at.. & $\begin{array}{l}\text { Further description of } \\
\text { problem }\end{array}$ & Management suggestion \\
\hline \multicolumn{4}{|l|}{ Sleep problems: } \\
\hline \multirow[t]{2}{*}{$\begin{array}{l}\text {-nocturnal motor } \\
\text { problems and early } \\
\text { morning akinesia }\end{array}$} & Physician & & $\begin{array}{l}\text {-Consider adjustment of dopaminergic therapy (e.g. } \\
\text { long-acting levodopa, dopamine agonist, rescue } \\
\text { levodopa during nighttime). }\end{array}$ \\
\hline & Nursing care & $\begin{array}{l}\text { The patient has motor } \\
\text { fluctuations decreasing the } \\
\text { patient ability in self-care, } \\
\text { mobility, cognition, speech, } \\
\text { mood etc. These fluctuations } \\
\text { (on-off periods) can differ } \\
\text { from day-to-day and hour-to- } \\
\text { hour basis. They can be } \\
\text { predictable or unpredictable. }\end{array}$ & $\begin{array}{l}\text { - Offer additional help during off-periods: e.g. assist } \\
\text { turning in bed, assist ADL-activities. (during off-period } \\
\text { more guidance is needed than during ON-period). } \\
\text { - Beware of the possibility of nocturia, a frequent } \\
\text { symptom in late-stage disease. } \\
\text { - Beware of risk of falling during nighttime, assist } \\
\text { patient when mobilizing. } \\
\text { - Use cueing techniques, mainly while assisting } \\
\text { patients out of bed and walking (e.g. counting, } \\
\text { breaking down a sequence). } \\
\text { - Consider appliances (eg. Lifting pole, light-weight } \\
\text { bed sheets) }\end{array}$ \\
\hline -Restless legs syndrome & Physician & & -Consider dopamine agonist or other RLS treatment \\
\hline $\begin{array}{l}\text {-REM-sleep behavioural } \\
\text { disorder }\end{array}$ & Physician & & $\begin{array}{l}\text {-Consider clonazepam or melatonin } \\
\text {-Consider bed rails or other protective measures to } \\
\text { safeguard bedroom environment. }\end{array}$ \\
\hline -Nocturia & Physician & & -Consider desmopressine \\
\hline \multirow[t]{2}{*}{-Insomnia } & Physician & & $\begin{array}{l}\text {-Review medication } \\
\text {-Consider advice on sleep hygiene measure's } \\
\text {-Consider hypnotics } \\
\text {-Consider referral to sleep centre }\end{array}$ \\
\hline & Nursing care & $\begin{array}{l}\text { Patients can have a variety } \\
\text { of motor and non-motor } \\
\text { problems that can interfere } \\
\text { with sleep (e.g. nocturnal } \\
\text { dystonia, urinary problems). } \\
\text { Nocturia, rem-sleep } \\
\text { behavioural disorder and } \\
\text { restless legs syndrome are } \\
\text { frequent. }\end{array}$ & $\begin{array}{l}\text { Advice and assist on sleep hygiene measures: } \\
\text { - Go to bed and get up at same time each day. } \\
\text { - Exercise regularly } \\
\text { - Spend some daytime outdoor in natural light } \\
\text { - Make bedroom as restful as possible (temperature } \\
\quad \text { cool, minimum noise, no/little distractions) } \\
\text { - Don't watch TV in bed } \\
\text { - Avoid drinking fluids at night } \\
\text { - Understand your sleep need (e.g. elderly people } \\
\text { sleep shorter and have more frequent day-nap time) }\end{array}$ \\
\hline \multicolumn{4}{|l|}{ Troublesome dystonia } \\
\hline -Off-time related & Physician & & -Adjustment of dopaminergic medication \\
\hline \multirow[t]{2}{*}{-Continuous } & Physician & & $\begin{array}{l}\text {-Consider referring to hospital for botulinum toxin } \\
\text { therapy } \\
\text {-Consider anticholinergic treatment }\end{array}$ \\
\hline & Nursing care & $\begin{array}{l}\text { Dystonia can decrease } \\
\text { ability in self-care, mobility. }\end{array}$ & $\begin{array}{l}\text {-Offer additional help during activities involving } \\
\text { impaired head/neck/extremity etc. } \\
\text {-Once recognized report to clinician }\end{array}$ \\
\hline \multirow[t]{2}{*}{$\underline{\text { Troublesome dyskinesia }}$} & Physician & & $\begin{array}{l}\text {-Consider adjustment of pharmacological regime (e.g. } \\
\text { fractionating levodopa, adjust levodopa or dopamine } \\
\text { agonist, discontinue or reduce dose MAO or COMT } \\
\text { inhibitors, start/adjust amantadine slow and low, } \\
\text { consider clozapine, consider advanced therapies) }\end{array}$ \\
\hline & Nursing care & $\begin{array}{l}\text { Dyskinesia can occur as a } \\
\text { complication of } \\
\text { antiparkinsonian medication. } \\
\text { It's occurrence is almost } \\
\text { inevitable in late stage } \\
\text { Parkinson disease and } \\
\text { frequently tolerated well by } \\
\text { patients if mild but can be } \\
\text { very disabling. }\end{array}$ & $\begin{array}{l}\text {-Discuss individual impact of dyskinesia with patient } \\
\text { and family } \\
\text {-Consider documenting presence of dyskinesia in diary }\end{array}$ \\
\hline $\begin{array}{l}\text { Troublesome motor } \\
\text { parkinsonism }\end{array}$ & Physician & & $\begin{array}{l}\text {-Adjustment of dopaminergic medication (eg. Increase } \\
\text { levodopa dose/number of doses, start/increase } \\
\text { dopamine agonist, start/increase COMT inhibitor, } \\
\text { start/increase MAO-inhibitor, consider advanced } \\
\text { therapies) } \\
\text {-Referral to OT/PT for cueing-strategies or } \\
\text { environmental adjustments }\end{array}$ \\
\hline
\end{tabular}




\begin{tabular}{|c|c|c|c|}
\hline Problem & Advice directed at.. & $\begin{array}{l}\text { Further description of } \\
\text { problem }\end{array}$ & Management suggestion \\
\hline & Nursing care & $\begin{array}{l}\text { The patient has motor } \\
\text { fluctuations decreasing the } \\
\text { patient ability in self-care, } \\
\text { mobility, cognition, speech, } \\
\text { mood etc. These fluctuations } \\
\text { (on-off periods) can differ on } \\
\text { day-to-day and hour-to-hour } \\
\text { basis. They can be } \\
\text { predictable or unpredictable. } \\
\text { Most frequent they are seen } \\
\text { prior to and directly after } \\
\text { medication intake. }\end{array}$ & $\begin{array}{l}\text {-Offer additional help during off-periods. } \\
\text {-Use cueing techniques (e.g. counting, breaking down } \\
\text { in sequence). } \\
\text {-Consider document presence of motor parkinsonism } \\
\text { in a diary } \\
\text {-Monitor and beware of risk of falling }\end{array}$ \\
\hline \multirow[t]{2}{*}{ Medication intake } & Physician & $\begin{array}{l}\text { Treatment with medications } \\
\text { potentially associated with } \\
\text { exacerbation of PD-related } \\
\text { problems are: (a)typical } \\
\text { antipsychotics other than } \\
\text { quetiapine or clozapine, } \\
\text { anticholinergics, } \\
\text { benzodiazepines, avoid pills } \\
\text { with protein rich meals, } \\
\text { antihypertensives in } \\
\text { hypotensive patients, } \\
\text { valproate, metoclopramide, } \\
\text { other medications with side } \\
\text { effect exacerbating PD } \\
\text { motor or non-motor } \\
\text { symptoms. }\end{array}$ & $\begin{array}{l}\text {-Adjust medication to expert advice. } \\
\text {-Schedule medication not to overlap with protein- } \\
\text { rich/heavy meal }\end{array}$ \\
\hline & Nursing care & $\begin{array}{l}\text { Daily functioning of the } \\
\text { patient can be highly } \\
\text { dependent on adequate and } \\
\text { timely intake of } \\
\text { levodopa/other } \\
\text { antiparkinsonian } \\
\text { medications. }\end{array}$ & $\begin{array}{l}\text {-Distribute levodopa precisely on set times and make } \\
\text { sure no protein-rich/heavy meal is consumed within } 30 \\
\text { minutes prior or } 60 \text { min afterwards. } \\
\text {-Monitor medication side-effects: dyskinesia, } \\
\text { hallucinations/psychosis, day-time sleepiness. } \\
\text {-If no fluctuations occur and patient suffers for the } \\
\text { larger part of the day from off-phenomena (e.g. } \\
\text { slowness, rigidity, tremor): consider the possibility of } \\
\text { undertreatment. Discuss observation with primary care } \\
\text { physician, elderly care specialist, geriatrician or } \\
\text { neurologist. } \\
\text {-Inform patient and family about the effect of levodopa } \\
\text { and heavy meals and support them to have an active } \\
\text { role in medication management. }\end{array}$ \\
\hline \multirow[t]{6}{*}{ Speech problems } & Physician & & $\begin{array}{l}\text {-Consider referral trained speech and language } \\
\text { therapist }\end{array}$ \\
\hline & \multirow[t]{4}{*}{$\begin{array}{l}\text { Speech and language } \\
\text { therapist }\end{array}$} & $\begin{array}{l}\text { The patient has clear } \\
\text { hypokinetic dysarthria which } \\
\text { can be improved to a certain } \\
\text { extent (or which is combined } \\
\text { with another form of } \\
\text { dysarthria). }\end{array}$ & $\begin{array}{l}\text {-Attempt intensive treatment, but also supervise and } \\
\text { instruct conversational partners. }\end{array}$ \\
\hline & & $\begin{array}{l}\text { The patient has very severe } \\
\text { hypokinetic dysarthria in } \\
\text { which little to no } \\
\text { improvement is possible. }\end{array}$ & $\begin{array}{l}\text { Focus on supervising and instructing conversational } \\
\text { partners or - when the patient has sufficient indicating } \\
\text { ability and cognitive skills - on teaching the use of a } \\
\text { communication aid. }\end{array}$ \\
\hline & & $\begin{array}{l}\text { The patient suffers primarily } \\
\text { from reduced word-finding } \\
\text { and communicative } \\
\text { problems. }\end{array}$ & $\begin{array}{l}\text { Suggest and discuss compensations, together with the } \\
\text { caregiver(s). }\end{array}$ \\
\hline & & $\begin{array}{l}\text { The patient has severe } \\
\text { apathy, meaning that he can } \\
\text { speak intelligibly but hardly } \\
\text { speaks anymore and prefers } \\
\text { to remain silent. }\end{array}$ & Explain and help with acceptance. \\
\hline & Nursing care & $\begin{array}{l}\text { Speech problems are } \\
\text { frequent in PD. Patients can } \\
\text { talk with a harsh, breathy, } \\
\text { softer, monotonous voice } \\
\text { with variable rate and short } \\
\text { rushes of speech and } \\
\text { imprecise consonants. }\end{array}$ & $\begin{array}{l}\text {-Adjust tempo of talking to patient's pace. } \\
\text {-Consider consulting SLT and enforce patient's } \\
\text { exercises. } \\
\text {-Several don't-s: do not talk for them, do not interrupt } \\
\text { them, do not insist to pronounce each word perfectly, } \\
\text { do not get irritated when patients cannot communicate, } \\
\text { do not ignore or isolate them. } \\
\text {-If indicated by SLT use communication aids: voice } \\
\text { amplifiers, pacing boards, pen and paper, word chart, } \\
\text { portable keybord with speech output }\end{array}$ \\
\hline
\end{tabular}




\begin{tabular}{|c|c|c|c|}
\hline Problem & Advice directed at.. & $\begin{array}{l}\text { Further description of } \\
\text { problem }\end{array}$ & Management suggestion \\
\hline \multirow[t]{4}{*}{ Hypersalivation } & Physician & & $\begin{array}{l}\text {-Consider referral trained speech and language } \\
\text { therapist } \\
\text {-Consider non-pharmacologic intervention: chewing } \\
\text { gum, tea. } \\
\text {-Consider pharmacological treatment: atropine drops } \\
\text { (e.g. } 0.5-2 \% \text {, glycopyrrolate, hyoscine patches, } \\
\text { botulinum toxin injection, scopolamine s.c. }\end{array}$ \\
\hline & \multirow[t]{2}{*}{$\begin{array}{l}\text { Speech and language } \\
\text { therapist }\end{array}$} & $\begin{array}{l}\text { The patient only has a } \\
\text { feeling of having } \\
\text { accumulation of saliva. }\end{array}$ & Explain the importance of swallowing in time. \\
\hline & & $\begin{array}{l}\text { The patient has a history of } \\
\text { drooling or the drooling is } \\
\text { visible. }\end{array}$ & $\begin{array}{l}\text { Try out modifications and cues, such as a cue for } \\
\text { closing the mouth, swallowing before standing up and } \\
\text { so on. } \\
\text { When results are insufficient, refer back to the } \\
\text { neurologist. }\end{array}$ \\
\hline & Nursing care & & $\begin{array}{l}\text {-Discuss impact of hypersalivation with patient. } \\
\text {-Help patient to attain an upright posture or sit straight } \\
\text { in chair. } \\
\text {-Monitor mouth hygiene. } \\
\text {-Monitor perioral skin problems }\end{array}$ \\
\hline \multirow[t]{5}{*}{ Dysphagia } & Physician & & $\begin{array}{l}\text {-Consider referral to trained speech and language } \\
\text { therapist } \\
\text {-Consider advanced directives and invasive therapy: } \\
\text { Feeding tube? Gastrostomie? }\end{array}$ \\
\hline & $\begin{array}{l}\text { Speech and language } \\
\text { therapist }\end{array}$ & $\begin{array}{l}\text { The patient has a minor } \\
\text { dysphagia, effected by } \\
\text { double tasking or } \\
\text { inadequate head position. }\end{array}$ & $\begin{array}{l}\text { Teach compensation strategies (e.g. posture, meal } \\
\text { volume) and cues to limit or prevent choking and } \\
\text { difficulty with swallowing pills, etc }\end{array}$ \\
\hline & $\begin{array}{l}\text { Speech and language } \\
\text { therapist }\end{array}$ & $\begin{array}{l}\text { Moderate to severe } \\
\text { dysphagia, including slow } \\
\text { eating and/or aspiration risk. }\end{array}$ & $\begin{array}{l}\text { Modify food consistencies or provide more assistance } \\
\text { or cues to maintain an acceptable speed and limit } \\
\text { fatigue, if necessary, in consultation with a dietician } \\
\text { and occupational therapist. }\end{array}$ \\
\hline & Dietician & $\begin{array}{l}\text { Problems with dietary intake } \\
\text { as well as weight loss can } \\
\text { result from chewing and } \\
\text { swallowing. }\end{array}$ & $\begin{array}{l}\text {-Detect nutritional inadequacies due to in-depth dietary } \\
\text { history : } \\
\text { - Current weight, height, BMI, weight history to } \\
\text { determine trend in weight over } 3-12 \text { months). } \\
\text { - Detailed dietary intake over last days to establish } \\
\text { eating patterns and habits. } \\
\text { - Dental and oral health } \\
\text { - swallowing and chewing difficulties } \\
\text { - medications } \\
\text { - level of disability, activity and resting patterns } \\
\text { - Instigate measures to correct deficiencies or nutrition- } \\
\text { related problems. } \\
\text { - texture-modified food } \\
\text { - supplements } \\
\text { - Identify ways to minimize practical difficulties with } \\
\text { swallowing and chewing. }\end{array}$ \\
\hline & Nursing care & $\begin{array}{l}\text { Signs of dysfagia can be: } \\
\text { excesize drooling, weight } \\
\text { loss, fear of swallowing, a } \\
\text { 'gurgly'voice, coughing } \\
\text { before, during or after meal } \\
\text { and pneumonia. }\end{array}$ & $\begin{array}{l}\text {-Modify food consistencies. } \\
\text { - Use compensations strategies, e.g. upright posture, } \\
\text { smaller portions (use dessertspoon, no bolus, no cup } \\
\text { with spout). } \\
\text {-Offer guidance, but avoid patient having to multitask } \\
\text { (e.g. eating and talking). } \\
\text {-Monitor weight }\end{array}$ \\
\hline$\underline{\text { Cognitive problems }}$ & Physician & $\begin{array}{l}\text { The patient has problems } \\
\text { with memory function, } \\
\text { attention, visuospatial ability } \\
\text { and a decreased ability to } \\
\text { plan ahead. This can be up } \\
\text { to the point of dementia. }\end{array}$ & $\begin{array}{l}\text {-Eliminate triggering factors: infection, metabolic } \\
\text { disorder, rectify fluid/electrolyte balance, treat sleep } \\
\text { disorder. } \\
\text {-Discuss impact of symptoms with patients and family. } \\
\text {-Consider to reduce polypharmacy: anticholinergics, } \\
\text { benzodiazepines, tricyclic antidepressants, tolterodine } \\
\text {-Consider referral to memory clinic } \\
\text {-If patient fulfills criteria consider rivastigmine. }\end{array}$ \\
\hline
\end{tabular}




\begin{tabular}{|c|c|c|c|}
\hline Problem & Advice directed at.. & $\begin{array}{l}\text { Further description of } \\
\text { problem }\end{array}$ & Management suggestion \\
\hline & Nursing care & & $\begin{array}{l}\text {-Patients can be slow in processing information. When } \\
\text { given enough time they may be able to communicate } \\
\text { better } \\
\text {-Enable patient in using memory aids, e.g. calendar or } \\
\text { agenda. } \\
\text {-Enable patient in following a clear and consistent } \\
\text { structure in the day. } \\
\text {-In early stages of dementia patients can benefit from } \\
\text { explicit information on time, location and persons } \\
\text { surrounding them (reality orientation). } \\
\text { - In later stage of dementia patients can benefit from } \\
\text { an approach in which patients aren't confronted which } \\
\text { their impairment and nurses can focus on the } \\
\text { emotional content of the communication with patients } \\
\text { (validation) }\end{array}$ \\
\hline \multirow[t]{2}{*}{ Psychotic symptoms } & Physician & $\begin{array}{l}\text { The patient is confused and } \\
\text { has a disturbed sense of } \\
\text { reality with hallucinations } \\
\text { and psychosis. }\end{array}$ & $\begin{array}{l}\text {-Control triggering factor: infection, metabolic } \\
\text { disorder, rectify fluid/electrolyte balance, treat sleep } \\
\text { disorder. } \\
\text {-Discuss impact of symptoms with patients and family. } \\
\text {-Evaluate cognition: Psychotic symptoms are more } \\
\text { frequent in patients with cognitive problems; patient } \\
\text { may need to be reviewed for developing dementia. } \\
\text {-Consider to reduce polypharmacy: anticholinergics, } \\
\text { anxiolytics/sedatives. } \\
\text {-Consider to phase out and stop antiparkinsonian } \\
\text { drugs: anti cholinergics, MAO inhibitors, amantadine, } \\
\text { dopamine agonists, COMT inhibitors, lastly levodopa. } \\
\text { Balance with costs of motor symptoms. } \\
\text {-Consider to add atypical antipsychotics. Evidence } \\
\text { only for clozapine. Alternative Quetiapine. } \\
\text {-Consider to add rivastigmine (in patients with } \\
\text { cognitive impairment). }\end{array}$ \\
\hline & Nursing care & & $\begin{array}{l}\text {-Actively inform and discuss the impact of } \\
\text { hallucinations and delusions with patients and family. } \\
\text {-Consider that the occurrence of hallucinations is more } \\
\text { frequent at night. } \\
\text {-Make sure patient residence is adequately lit. } \\
\text {-Give family instructions on how to cope with } \\
\text { hallucinations and delusions. }\end{array}$ \\
\hline \multirow[t]{3}{*}{ Depression } & Physician & & $\begin{array}{l}\text {-Consider to optimize antiparkinsonian therapy } \\
\text {-Consider dopamine agonist, antidepressant agent } \\
\text { (e.g. desipramine, nortriptiline, venlafaxine) } \\
\text {-Consider referral to psychiatrist. }\end{array}$ \\
\hline & $\begin{array}{l}\text { Psychologist/ } \\
\text { psychiatrist }\end{array}$ & $\begin{array}{l}\text { The patient has fluctuations } \\
\text { in mood. Depression is } \\
\text { common in patients with } \\
\text { Parkinson disease. }\end{array}$ & $\begin{array}{l}\text {-Consider dopamine agonist, antidepressant agent } \\
\text { (first choice SSRI) or referral psychiatrist. } \\
\text {-Cognitive Behavioral therapy }\end{array}$ \\
\hline & Nursing care & & $\begin{array}{l}\text {-Does mood fluctuate; i.e is it nonmotor fluctuation? } \\
\text {-Discuss impact of disease with patient and family. }\end{array}$ \\
\hline \multirow[t]{2}{*}{ Daytime sleepiness } & Physician & & $\begin{array}{l}\text {-Optimize nighttime sleep, see "sleep problems" } \\
\text {-Evaluate drugs (consider reducing dopamine agonist, } \\
\text { or other sedatives mediation). }\end{array}$ \\
\hline & Nursing care & $\begin{array}{l}\text { Daytime sleepiness can be a } \\
\text { consequence of somatic } \\
\text { disease, a complication of } \\
\text { medication or can be an } \\
\text { arousal problem. }\end{array}$ & $\begin{array}{l}\text {-Observe circadian rhythm } \\
\text {-Offer day-time activities } \\
\text {-Explain and assist in sleep hygiene measures. } \\
\text {-Consult general care physician, movement disorder } \\
\text { specialist or occupational therapist. }\end{array}$ \\
\hline \multirow[t]{2}{*}{ Pain } & Physician & $\begin{array}{l}\text { Pain can be: RLS, dystonia, } \\
\text { sensory-type pain like } \\
\text { paresthaesias, burning, } \\
\text { coldness, numbness. Pain } \\
\text { related to motor fluctuations. } \\
\text { Musculoskeletal pain. }\end{array}$ & -Treat according to cause with medication \\
\hline & Physiotherapy & $\begin{array}{l}\text { The intervention, will } \\
\text { address pain education, } \\
\text { including explaining the } \\
\text { influence of fear, and the } \\
\text { importance of staying } \\
\text { physical active. However, } \\
\text { none of these have been } \\
\text { evaluated in PD patient.s }\end{array}$ & $\begin{array}{l}\text {-Exercising including range of motion exercises and } \\
\text { postural adjustments for musculoskeletal and } \\
\text { neuropathic pain; graded increase of activity; time- } \\
\text { dependent exercising, instead of pain-dependent: } \\
\text { agree upon steps on forehand } \\
\text {-Pain relieve through TENS and manual therapy } \\
\text {-Relaxation } \\
\text {-Peripheral desensitization techniques } \\
\text {-Motor imagery and mirror therapy } \\
\text {-Cognitive strategies }\end{array}$ \\
\hline
\end{tabular}




\begin{tabular}{|c|c|c|c|}
\hline Problem & Advice directed at.. & $\begin{array}{l}\text { Further description of } \\
\text { problem }\end{array}$ & Management suggestion \\
\hline & & & $\begin{array}{l}\text {-A Visual Analogue Scale for pain may be used for } \\
\text { evaluation }\end{array}$ \\
\hline & Nursing care & & $\begin{array}{l}\text {-Distraction } \\
\text {-VAS-score }\end{array}$ \\
\hline \multirow[t]{3}{*}{ Constipation } & Physician & $\begin{array}{l}\text { Autonomic dysfunction is } \\
\text { common in Parkinson } \\
\text { disease:. Symptoms include } \\
\text { urinary dysfunction, } \\
\text { constipation, erectile } \\
\text { dysfunction, orthostatic } \\
\text { hypotension, weight loss, } \\
\text { dysphagia, excessive } \\
\text { sweating, excessive saliva. }\end{array}$ & $\begin{array}{l}\text {-Exclude other causes of constipation. } \\
\text {-Advice on fiber intake, fluid intake and exercise. } \\
\text {-Reduce anticholinergics } \\
\text {-Consider macrogol, other laxatives }\end{array}$ \\
\hline & Dietician & $\begin{array}{l}\text { Constipation is frequent in } \\
\text { patients affecting over } 50 \%\end{array}$ & $\begin{array}{l}\text {-Detailed history on fiber and fluid intake. } \\
\text {-Advice on fiber intake. } \\
\text {-Advice on exercise }\end{array}$ \\
\hline & Nursing care & & $\begin{array}{l}\text {-Advice and assist adequate fluid intake (at least } 8 \\
\text { glasses a day). } \\
\text {-Make sure patients has adequate fiber intake. } \\
\text {-Offer help in accessing toilets } \\
\text {-Offer help with exercise. } \\
\text { - Help with good posture while sitting on the toilet. } \\
\text {-Help patients with setting time to go to the toilet and } \\
\text { not putting of the urge. }\end{array}$ \\
\hline \multirow[t]{2}{*}{$\underline{\text { Urinary symptoms }}$} & Physician & $\begin{array}{l}\text { Autonomic dysfunction is } \\
\text { common in Parkinson } \\
\text { disease:. Symptoms include } \\
\text { urinary dysfunction, } \\
\text { constipation, erectile } \\
\text { dysfunction, orthostatic } \\
\text { hypotension, weight loss, } \\
\text { dysphagia, excessive } \\
\text { sweating, excessive saliva. }\end{array}$ & $\begin{array}{l}\text {-Assess autonomic dysfunction. } \\
\text {-Exclude urinary tract infection, polyuria due to } \\
\text { diabetes. } \\
\text {-Pre- and post void bladder scan to exclude urinary } \\
\text { retention. } \\
\text {-Consider to reduce intake of fluid after } 6 \mathrm{pm} \text {. } \\
\text {-Consider referral to (neuro)urologist of continence } \\
\text { advisor } \\
\text {-For urge complaints peripheral acting anticholinergic } \\
\text { medication could be considered } \\
\text {-For nocturia, desmopressine could be considered. }\end{array}$ \\
\hline & Nursing care & & $\begin{array}{l}\text {-Observe urinary symptoms } \\
\text {-Advice and assist adequate fluid intake (concentrated } \\
\text { urine can irritate the bladder). } \\
\text {-Help access toilet } \\
\text {-Continence material } \\
\text {-If indicated by GP/urologist: } \\
\text {-Bladder training (with support of specialist continence } \\
\text { expert) } \\
\text {-Intermittent catheterization. }\end{array}$ \\
\hline \multirow[t]{3}{*}{ Orthostatic hypotension } & Physician & $\begin{array}{l}\text { Autonomic dysfunction is } \\
\text { common in Parkinson } \\
\text { disease:. Symptoms include } \\
\text { urinary dysfunction, } \\
\text { constipation, erectile } \\
\text { dysfunction, orthostatic } \\
\text { hypotension, weight loss, } \\
\text { dysphagia, excessive } \\
\text { sweating, excessive saliva. }\end{array}$ & $\begin{array}{l}\text {-Consider documenting blood pressure (supine, } 1 \\
\text { minute upright, } 3 \text { minutes upright) } \\
\text {-Consider to increase salt and fluid intake } \\
\text {-Consider fludrocortison or midodrine } \\
\text {-Consider to phase out and stop anti cholinergics, } \\
\text { MAO inhibitors, amantadine, dopamine agonists } \\
\text {-Consider stopping antihypertensives, tricyclic } \\
\text { antidepressants, nitrates, alpha-blockers used to treat } \\
\text { urinary disturbances. }\end{array}$ \\
\hline & Physiotherapy & $\begin{array}{l}\text { Orthostatic hypotension is } \\
\text { frequent in patients. }\end{array}$ & See advice "increased fall risk". \\
\hline & Nursing care & & $\begin{array}{l}\text {-Measure orthostatic hypotension regularly. } \\
\text {-Advice and assist patient in avoiding aggravating } \\
\text { factors like alcohol, warm environment. } \\
\text {-Assist in adequate fluid intake (8 glasses a day). } \\
\text {-Assist in adequate salt intake (e.g. bouillon) } \\
\text {-Assist patient in adequately performing hypotension } \\
\text { inducing manoevres. } \\
\text {-Head-up tilt of the bed at night (or add extra pillows) } \\
\text {-Wear elastic stockings } \\
\text {-Highlight postprandial affects }\end{array}$ \\
\hline
\end{tabular}




\begin{tabular}{|c|c|c|c|}
\hline Problem & Advice directed at.. & $\begin{array}{l}\text { Further description of } \\
\text { problem }\end{array}$ & Management suggestion \\
\hline \multirow{2}{*}{$\begin{array}{l}\text { Mobility and contractures } \\
\text { Patient is unable to } \\
\text { mobilize } \\
\text { independently/safely } \\
\text { (indoors and outdoors) } \\
\text { / } \\
\text { Risk of contractures or } \\
\text { patient has inadequate } \\
\text { positioning during } \\
\text { activities or rest }\end{array}$} & Physician & & $\begin{array}{l}\text {-Optimize medication including possibility of advanced } \\
\text { treatment } \\
\text {-Consider referral physiotherapist }\end{array}$ \\
\hline & $\begin{array}{l}\text { Physiotherapy/ } \\
\text { nursing care/ } \\
\text { occupational therapist }\end{array}$ & $\begin{array}{l}\text { External cueing and } \\
\text { attentional strategies are } \\
\text { used to replace internal } \\
\text { control of automated and } \\
\text { repetitive movements. }\end{array}$ & $\begin{array}{l}\text {-Support exercise } \\
\text {-External cues are defined as temporal or spatial } \\
\text { external stimuli associated with the initiation and } \\
\text { ongoing facilitation of motor activity (gait). They can be } \\
\text { auditory, visual or tactile. } \\
\text { - Not all PD-patients benefit from using cues. As yet, } \\
\text { there is no insight into which patients benefit and } \\
\text { which do not. However, if a patient benefits from cues, } \\
\text { this will be visible after one single training session. } \\
\text {-Attentional strategies are distinct from cueing as they } \\
\text { need to be self-generated and provide an internal } \\
\text { focus on the movement. Often they are used in } \\
\text { combination. } \\
\text {-Both cueing and attentional strategies can be one-off, } \\
\text { merely to initiate movement, or continuous, to prevent } \\
\text { freezing of gait. } \\
\text {-Prevent complications (e.g. passive movement of } \\
\text { severely rigid extremity) } \\
\text {-Consider appliances }\end{array}$ \\
\hline \multirow[t]{3}{*}{ Falls } & Physician & $\begin{array}{l}\text { Consider as causes of } \\
\text { falling: freezing, orthostatic } \\
\text { hypotension, comorbidity } \\
\text { (including sensory } \\
\text { impairment), medication, } \\
\text { instability, dystonia, } \\
\text { dyskinesia. }\end{array}$ & $\begin{array}{l}\text {-Optimize medication } \\
\text {-Consider referral physiotherapist }\end{array}$ \\
\hline & Physiotherapist & & $\begin{array}{l}\text {-Improvement of strength and balance, } \\
\text {-Reduction of fear (to fall or not being able to get up } \\
\text { from the floor), } \\
\text {-Practice posture changes } \\
\text {-Information regarding (walking) aids } \\
\text {-Due to the reduced/absence postural reflexes, } \\
\text { learning how to fall is not recommended. However, fall } \\
\text { prevention training (e.g. including pushes, pull and } \\
\text { increasing confidence) may be effective. } \\
\text {-Walking aids, such as a walking-stick and walker, can } \\
\text { increase the independence and safety of patient. } \\
\text { However, at the same time they can make walking } \\
\text { more complex and more difficult, as by using these } \\
\text { aids the performance of a dual task is required. } \\
\text { Furthermore, inadequate use of, for example, a } \\
\text { walker, can worsen the posture. Patient with freezing } \\
\text { episodes benefit more from a walker with so-called } \\
\text { compression brakes, which are activated when a } \\
\text { patient leans on the walker, and are advised against } \\
\text { using a walking frame. }\end{array}$ \\
\hline & Nursing care & $\begin{array}{l}\text { Nurses and nurse } \\
\text { assistance can take practical } \\
\text { measures to reduce risk of } \\
\text { falling. }\end{array}$ & $\begin{array}{l}\text {-Ask routinely whether patients has been falling. } \\
\text {-Take fall prevention measures depending on cause } \\
\text { (identify causes in concert with fysiotherapist, } \\
\text { physician) } \\
\text {-Offer guidance with mobility problems. } \\
\text {-Coach patient to use walker. } \\
\text { Assist patients in using glasses and hearing aids. }\end{array}$ \\
\hline $\begin{array}{l}\text { Inadequate home } \\
\text { environment }\end{array}$ & Physician & $\begin{array}{l}\text { Inadequate home } \\
\text { environment can increase } \\
\text { risk of complications (e.g. } \\
\text { falling) and decrease } \\
\text { independence }\end{array}$ & $\begin{array}{l}\text {-Consider referral for assessing and adjusting home } \\
\text { environment according to local facilities }\end{array}$ \\
\hline
\end{tabular}




\begin{tabular}{|c|c|c|c|}
\hline Problem & Advice directed at.. & $\begin{array}{l}\text { Further description of } \\
\text { problem }\end{array}$ & Management suggestion \\
\hline \multirow[t]{2}{*}{$\begin{array}{l}\text { Daytime structure } \\
\text { Patient is dissatisfied } \\
\text { about day structure/ } \\
\text { activity engagement }\end{array}$} & \multirow[t]{2}{*}{ Occupational therapy } & $\begin{array}{l}\text { Assistance is required in } \\
\text { performing (parts of) some } \\
\text { activities: } \\
\text { Treatment focus is on } \\
\text { optimizing both activity } \\
\text { performance and } \\
\text { participation. }\end{array}$ & $\begin{array}{l}\text { Interventions may include: } \\
\text {-Use of alternative and compensatory strategies to } \\
\text { improve task performance: e.g. use of cues, } \\
\text { reorganizing complex performance sequences, } \\
\text { focused attention, cognitive strategies like problem } \\
\text { solving and planning strategies, as well as time } \\
\text { pressure management. } \\
\text {-Advice on optimizing daily routines (e.g. fatigue } \\
\text { management) and simplifying activities } \\
\text {-Advice on appropriate assistive devices and } \\
\text { modification in the home environment to enhance } \\
\text { independence, efficiency and safety. } \\
\text { Specific caregiver interventions: } \\
\text {-information provision (impact of disease on daily } \\
\text { functioning of patient, possible care resources, aids } \\
\text { and adaptations) } \\
\text {-training skills to support/supervise patient in daily } \\
\text { activities, while considering own well being } \\
\text { (occupational balance). }\end{array}$ \\
\hline & & $\begin{array}{l}\text { Assistance is required in } \\
\text { most activities: } \\
\text { Treatment focus is on } \\
\text { enabling adapted } \\
\text { involvement in meaningful } \\
\text { activities and prevention of } \\
\text { complications due to } \\
\text { immobility. Depending on } \\
\text { Patient's capacity to change } \\
\text { methods or routines, } \\
\text { interventions may include all } \\
\text { mentioned suggestions. }\end{array}$ & $\begin{array}{l}\text { Additional attention should be given to: } \\
\text {-Exploring opportunities for engagement in meaningful } \\
\text { (leisure) activities } \\
\text {-Appropriate positioning ( } 24 \mathrm{hr} \text { ) } \\
\text {-Information, support, advice on appropriate/alternative } \\
\text { living arrangements } \\
\text {-Information, support and advice for caregivers (i.e } \\
\text { safety in manual handling, maintaining own wellbeing } \\
\text { (occupational balance)) }\end{array}$ \\
\hline \multirow{2}{*}{$\begin{array}{l}\text { Caregiver burden } \\
\text { Formal or informal } \\
\text { caregiver has questions } \\
\text { on how and when to } \\
\text { assist the patient. }\end{array}$} & Physician & & -Refer to local support for informal caregivers \\
\hline & Nursing care & & $\begin{array}{l}\text {-Have regular contact with informal caregiver and } \\
\text { assess impact of disease. }\end{array}$ \\
\hline
\end{tabular}


Appendix D. Frequencies of treatment recommendations

Number of expert recommendation given per guideline-defined recommendation

\begin{tabular}{|c|c|c|c|c|}
\hline & \multicolumn{4}{|c|}{ Number of expert recommendation given per guideline-defined recommendation } \\
\hline \multirow[t]{2}{*}{ Indication } & \multicolumn{4}{|c|}{ Type of recommendation } \\
\hline & \multicolumn{2}{|c|}{ Pharmacological } & Referral & General advice \\
\hline Overall & \multicolumn{2}{|c|}{93} & 73 & 50 \\
\hline $\begin{array}{l}\text { Motor } \\
\text { symptoms }\end{array}$ & \multicolumn{2}{|c|}{60} & 40 & 18 \\
\hline $\begin{array}{l}\text { Motor } \\
\text { parkinsonism }\end{array}$ & \multicolumn{2}{|c|}{$\begin{array}{l}\text { Adjustment of dopaminergic treatment } \\
38\end{array}$} & $\begin{array}{l}\text { Referral to PT / OT } \\
26 \\
\end{array}$ & $\begin{array}{c}\text { Tips for nursing care } \\
8\end{array}$ \\
\hline Dystonia & \multicolumn{2}{|c|}{$\begin{array}{c}\text { Adjustment of dopaminergic treatment } \\
8\end{array}$} & $\begin{array}{l}\text { Referral to PT/OT } \\
7\end{array}$ & $\begin{array}{c}\text { Tips for nursing care } \\
3\end{array}$ \\
\hline $\begin{array}{l}\text { Troublesome } \\
\text { dyskinesia }\end{array}$ & $\begin{array}{c}\text { Fractioning } \\
\text { dopaminergic } \\
\text { treatment } \\
1\end{array}$ & $\begin{array}{l}\text { Start / adjust } \\
\text { amantadine } \\
0 \\
0\end{array}$ & Referral to PT / OT & Tips for nursing care \\
\hline $\begin{array}{l}\text { Off-time larger } \\
\text { than } 50 \% \text { of the } \\
\text { waking day }\end{array}$ & \multicolumn{2}{|c|}{$\begin{array}{c}\text { Adjustment of dopaminergic treatment } \\
9\end{array}$} & $\begin{array}{l}\text { Referral to PT / OT } \\
3\end{array}$ & $\begin{array}{c}\text { Tips for nursing care } \\
4\end{array}$ \\
\hline $\begin{array}{l}\text { Error in } \\
\text { medication } \\
\text { intake }\end{array}$ & \multicolumn{2}{|c|}{$\begin{array}{c}\text { Stop medication potentially associated with PD- } \\
\text { exacerbation } \\
4\end{array}$} & - & $\begin{array}{c}\text { Tips for nursing care } \\
1\end{array}$ \\
\hline $\begin{array}{l}\text { Non-motor } \\
\text { symptoms }\end{array}$ & \multicolumn{2}{|c|}{9} & 26 & 24 \\
\hline Speech problems & \multicolumn{2}{|c|}{-} & $\begin{array}{c}\text { Referral to SLT } \\
10 \\
\end{array}$ & $\begin{array}{c}\text { Tips for nursing care } \\
8 \\
\end{array}$ \\
\hline Hypersalivation & \multicolumn{2}{|c|}{$\begin{array}{c}\text { Medication for hypersalivation } \\
5 \\
\end{array}$} & $\begin{array}{l}\text { Referral to SLT } \\
9 \\
\end{array}$ & $\begin{array}{c}\text { Tips for nursing care } \\
8\end{array}$ \\
\hline Dysphagia & \multicolumn{2}{|c|}{-} & $\begin{array}{c}\text { Referral to SLT /dietitian } \\
5 \\
\end{array}$ & $\begin{array}{c}\text { Tips for nursing care } \\
3\end{array}$ \\
\hline Pain & \multicolumn{2}{|c|}{$\begin{array}{c}\text { Start/ adjust pain medication } \\
1\end{array}$} & - & $\begin{array}{c}\text { Tips for nursing care } \\
1\end{array}$ \\
\hline Constipation & \multicolumn{2}{|c|}{$\begin{array}{c}\text { Start/ adjust laxative } \\
1 \\
\end{array}$} & - & $\begin{array}{c}\text { Tips for nursing care } \\
2\end{array}$ \\
\hline $\begin{array}{l}\text { Orthostatic } \\
\text { hypotension }\end{array}$ & \multicolumn{2}{|c|}{$\begin{array}{l}\text { Evaluate pharmacological treatment } \\
2\end{array}$} & $\begin{array}{c}\text { Referral PT } \\
2 \\
\end{array}$ & $\begin{array}{c}\text { Tips for nursing care } \\
2\end{array}$ \\
\hline $\begin{array}{l}\text { Mental health } \\
\text { problems }\end{array}$ & \multicolumn{2}{|c|}{24} & 7 & 8 \\
\hline $\begin{array}{l}\text { Parkinson } \\
\text { disease } \\
\text { dementia }\end{array}$ & \multicolumn{2}{|c|}{ Start/ adjust cholinesterase inhibitor } & $\begin{array}{c}\text { Referral to } \\
\text { psychologist/psychiatrist } \\
4 \\
\end{array}$ & $\begin{array}{c}\text { Tips for nursing care } \\
4 \\
\end{array}$ \\
\hline Psychosis & $\begin{array}{l}\text { Phase out or stop } \\
\text { medication } \\
1\end{array}$ & $\begin{array}{l}\text { Start/adjust clozapine or } \\
\text { quitiapine } \\
2\end{array}$ & $\begin{array}{c}\text { Referral to } \\
\text { psychologist/psychiatrist } \\
2\end{array}$ & $\begin{array}{c}\text { Tips for nursing care } \\
2\end{array}$ \\
\hline Depression & $\begin{array}{l}\text { Adjust dopaminergic } \\
\text { medication } \\
7\end{array}$ & $\begin{array}{c}\text { Start antidepressant } \\
4\end{array}$ & $\begin{array}{c}\text { Referral to } \\
\text { psychologist/psychiatrist } \\
1\end{array}$ & $\begin{array}{c}\text { Tips for nursing care } \\
2\end{array}$ \\
\hline
\end{tabular}

Abbrevations: Physiotherapy (PT), Occupational therapy (OT), Speech and language therapy (SLT) 
Appendix E. sensitivity analysis of the outcomes for the per protocol analysis

Beta, (95\% confidence interval lower bound to higher bound), $p$-value

\begin{tabular}{r|cc} 
& $\begin{array}{c}\text { Sample } \\
\text { size }\end{array}$ & Intervention \\
UPDRS-II & 89 & Intention-to-treat \\
PDQ8 & 39 & $-1.2(-4.2$ to 1.8$)$ \\
& & $-3.9(-7.1$ to -0.7$)$ \\
$\mathrm{p}=0.02$
\end{tabular}

Per protocol (Intervention: partially or completely followed. Comparison: controls and not followed

\begin{tabular}{c|cc} 
UPDRS-II & 73 & $-1.1(-3.6$ to 1.3$)$ \\
UPDRS-I & 73 & $p=0.37$ \\
& & $-1.1(-2.2$ to -0.4$)$ \\
UPDRS-tot & 72 & $p=0.04$ \\
& & $-7.4(-14.6$ to -0.2$)$ \\
PDQ-8 & 38 & $p=0.04$ \\
& & $-2.7(-5.1$ to -0.3$)$ \\
LEDD & 73 & $p=0.03$ \\
& & $+165(51$ to 279$)$ \\
& & $p=0.01$
\end{tabular}

Sensitivity analysis

Per protocol 2 (intervention: completely followed. Comparison: not followed and controls. Not included: partially)

\begin{tabular}{r|cc} 
UPDRS-II & 51 & $-0.1(-3.5$ to 3.3$)$ \\
UPDRS-I & 51 & $\mathrm{p}=0.96$ \\
& & $-1.0(-2.1$ to 0.1$)$ \\
$\mathrm{p}=0.08$ & $-7.0(-16.9$ to 3.0$)$ \\
UPDRS-tot & 52 & $\mathrm{p}=0.17$ \\
& & $-3.0(-5.9$ to -0.1$)$ \\
PDQ-8 & 29 & $\mathrm{p}=0.04$ \\
& & $+182(80$ to 285$)$ \\
LEDD & 52 & $\mathrm{p}=0.001$
\end{tabular}

Per protocol 3 (Intervention: partially or completely followed. Comparison: controls. Not included: not followed)

\begin{tabular}{r|cc} 
UPDRS-II & 55 & $-1.5(-4.6$ to 1.6 \\
UPDRS-I & 55 & $p=0.33$ \\
& & $-1.1(-2.5$ to 0.3$)$ \\
$\mathrm{p}=0.13$ \\
UPDRS-tot & 54 & $-9.7(-18.7$ to -0.9$)$ \\
& & $p=0.03$ \\
PDQ-8 & 27 & $-4.0(-7.1$ to -0.9$)$ \\
& & $p=0.01$ \\
LEDD & 55 & $+159(-0.8$ to 319$)$ \\
& & $p=0.05$
\end{tabular}

Per protocol 4 (Intervention: completely and partially followed. Comparison: not followed. Not included: controls

\begin{tabular}{c|cc} 
UPDRS-II & 53 & $-0.7(-3.7$ to 2.4$)$ \\
UPDRS-I & 54 & -0.65 \\
& & $-1.2(-2.7$ to 0.25$)$ \\
$\mathrm{p}=0.10$ & $-5.3(-14.4$ to 3.8$)$ \\
UPDRS-tot & 53 & $\mathrm{p}=0.25$ \\
& & $-2.0(-4.6$ to 0.7$)$ \\
PDQ-8 & 30 & $\mathrm{p}=0.14$ \\
& & $+148(-20$ to 317$)$ \\
LEDD & 55 & $\mathrm{p}=0.08$
\end{tabular}

Per protocol 5 (Intervention: partially followed. Comparison: not followed and controls. Not included: completely

\begin{tabular}{c|cc} 
UPDRS-II & 51 & $-1.7(-4.7$ to 1.3$)$ \\
UPDRS-I & 51 & $\mathrm{p}=0.26$ \\
& & $-1.1(-2.5$ to 0.2$)$ \\
$\mathrm{u}=0.10$ \\
UPDRS-tot & 50 & $-5.9(-14.2$ to 2.4$)$ \\
& & $\mathrm{p}=0.16$ \\
PDQ-8 & 29 & $-1.7(-5.3$ to 1.8$)$
\end{tabular}




\begin{tabular}{|c|c|c|}
\hline & & $p=0.31$ \\
\hline$\angle E D D$ & 52 & $\begin{array}{c}+154\left(\begin{array}{c}14.7 \text { to } 293) \\
p=0.03\end{array}\right.\end{array}$ \\
\hline
\end{tabular}

Per protocol 6 (Intervention: completely followed. Comparison: partially followed, not-followed and controls

\begin{tabular}{c|cc} 
UPDRS-II & 72 & $+0.48(-2.5$ to 3.4$)$ \\
UPDRS-I & 72 & $-0.4(-1.7$ to 0.9$)$ \\
& & $p=0.55$ \\
UPDRS-tot & 73 & $-4.7(-13.3$ to 4.0$)$ \\
& & $p=0.28$ \\
PDQ-8 & 38 & $-2.3(-4.9$ to 0.4$)$ \\
& & $p=0.09$ \\
LEDD & 73 & $+114(-26$ to 253$)$ \\
& & $p=0.11$
\end{tabular}

